\title{
Two prehistoric short-cists and an early medieval long-cist cemetery with dug graves on Kingston Common, North Berwick, East Lothian
}

\author{
by Ian Suddaby"
}

with contributions by Paul Duffy, Adam Jackson, John Lawson, Ann MacSween \& Graeme Warren

Illustrations by George Mudie, Kevin Hicks \& Leeanne Whitelaw *CFA Archaeology Ltd, Old Engine House, Eskmills Park, Musselburgh, East Lothian EH21 7PQ 
Published by the Society of Antiquaries of Scotland, www.socantscot.org.uk with Historic Scotland, www.historic-scotland.gov.uk and the Council for British Archaeology, www.britarch.ac.uk

Editor Helen Bleck

Produced by Archétype Informatique, www.archetype-it.com

ISBN: 9780903903653

ISSN: $1773-3803$

Requests for permission to reproduce material from a $S A I R$ report should be sent to the Director of the Society of Antiquaries of Scotland, as well as to the author, illustrator, photographer or other copyright holder.

Copyright in any of the Scottish Archaeological Internet Reports series rests with the SAIR Consortium and the individual authors.

The maps are reproduced from Ordnance Survey material with the permission of Ordnance Survey on behalf of The Controller of Her Majesty's Stationery Office. (C) Crown copyright 2001. Any unauthorised reproduction infringes Crown copyright and may lead to prosecution or civil proceedings. Historic Scotland Licence No GD 03032G, 2002.

The consent does not extend to copying for general distribution, advertising or promotional purposes, the creation of new collective works or resale. 


\section{CONTENTS}

List of Illustrations . . . . . . . . . . . . . . . . . . . . . . . . . . iv

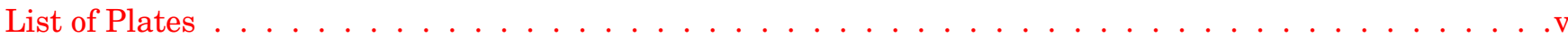

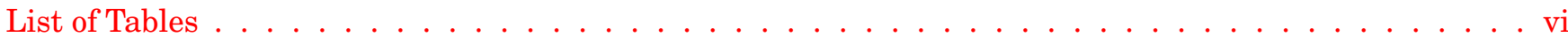

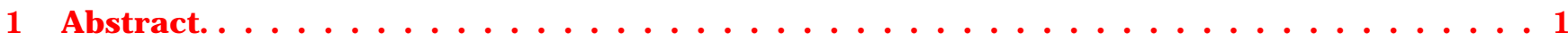

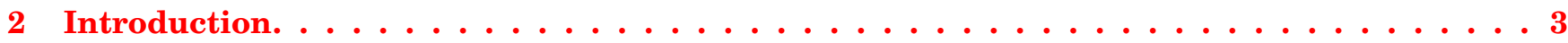

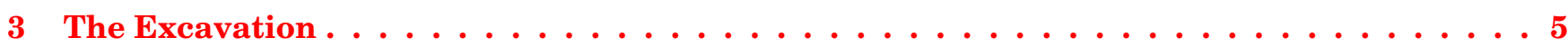

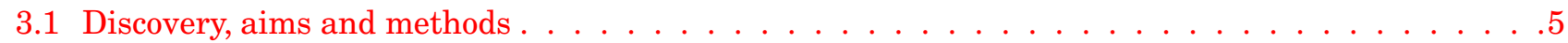

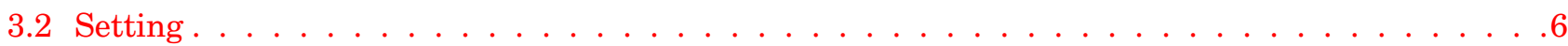

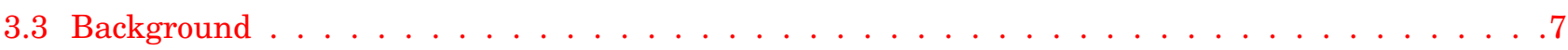

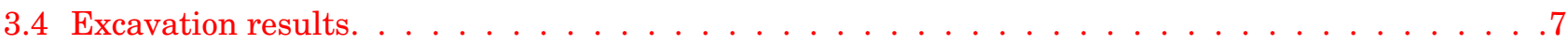

3.5 Coarse stone by Adam Jackson . . . . . . . . . . . . . . . . . . . . . . . . . 12

3.6 Chipped stone by Graeme Warren . . . . . . . . . . . . . . . . . . . . . . . . . . . . . . . . . . 14

3.7 Prehistoric pottery by Ann MacSween . . . . . . . . . . . . . . . . . . . . . . . . . . . 14

3.8 Medieval and later ceramics by John Lawson . . . . . . . . . . . . . . . . . . . . . . . . . . . 14

3.9 Skeletal remains by Paul Duffy. . . . . . . . . . . . . . . . . . . . . . . . . . . 15

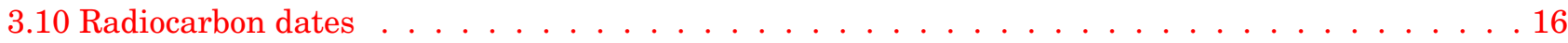

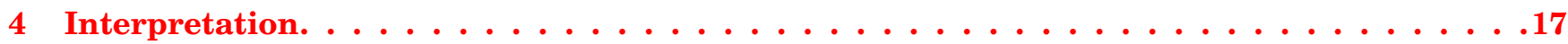

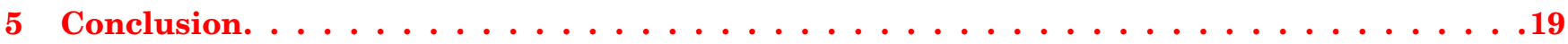

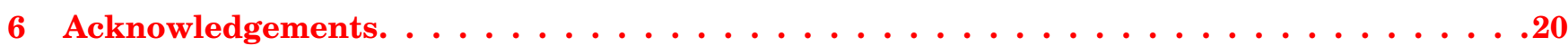

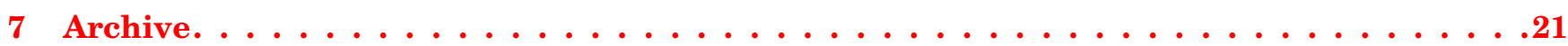

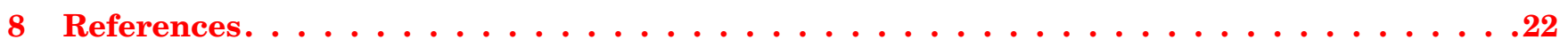




\section{LIST OF ILLUSTRATIONS}

General location map, and the village itself, with the Study Area indicated . . . . . . . . . . . .2 Kingston Hill shown on an extract from the OS 1st Edition map of 1854 . . . . . . . . . . . . . . .3 The Study Area. . . . . . . . . . . . . . . . . . . . . . . . . . . 6 Trench 1 , plan . . . . . . . . . . . . . . . . . . . . . . . Trench 1, north facing section (a), including the west-facing section in the trench extension to the south $(b) \ldots \ldots \ldots \ldots \ldots$

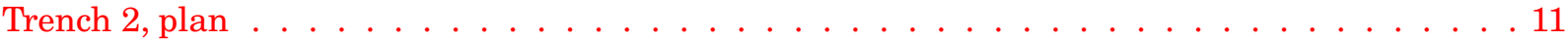
Trench 2 , west-facing section . . . . . . . . . . . . . . . . . . . . 11 Trench 5, plan showing long-cists F52-5, all formed from volcanic stone . . . . . . . . . . . . . 12 Trench 5 north-facing section showing soil layers over long-cists . . . . . . . . . . . . . 13 Water pipe trench, west-facing section . . . . . . . . . . . . . . . 13 White Gritty Ware pottery, small finds $1,13,39 \ldots \ldots 14$ Plan of long-cist cemeteries south of the River Forth . . . . . . . . . . . . . . . . . . 17 


\section{LIST OF PLATES}

1 The view from the parapet of Fenton Tower . . . . . . . . . . . . . . . . . . . .4

$2 \quad$ Kingston Common and Fenton Tower from near Rockwell Farm . . . . . . . . . . . . . . . . .4

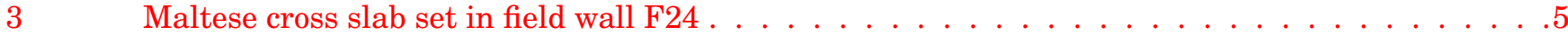

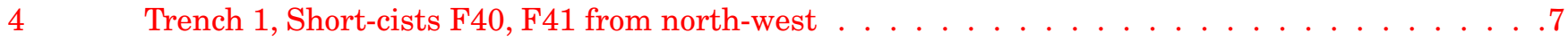

$5 \quad$ Trench 2, Long-cist F44 underlying wall F24 . . . . . . . . . . . . . . . . . . . . . . . 12 


\section{LIST OF TABLES}

1

Radiocarbon dates . . . . . . . . . . . . . . . . . . . . . 16 


\section{ABSTRACT}

Human remains were discovered during the laying of a water pipe to service the refurbished Fenton Tower at Kingston, near North Berwick, in 2001. Two short-cist burials, thirty-eight long-cist burials and bank-defined terraces containing dug graves and a possible chapel (NT58SW 152) were found. It is suggested that three main periods of burial are represented, spanning the Neolithic to the early second millennium AD. 


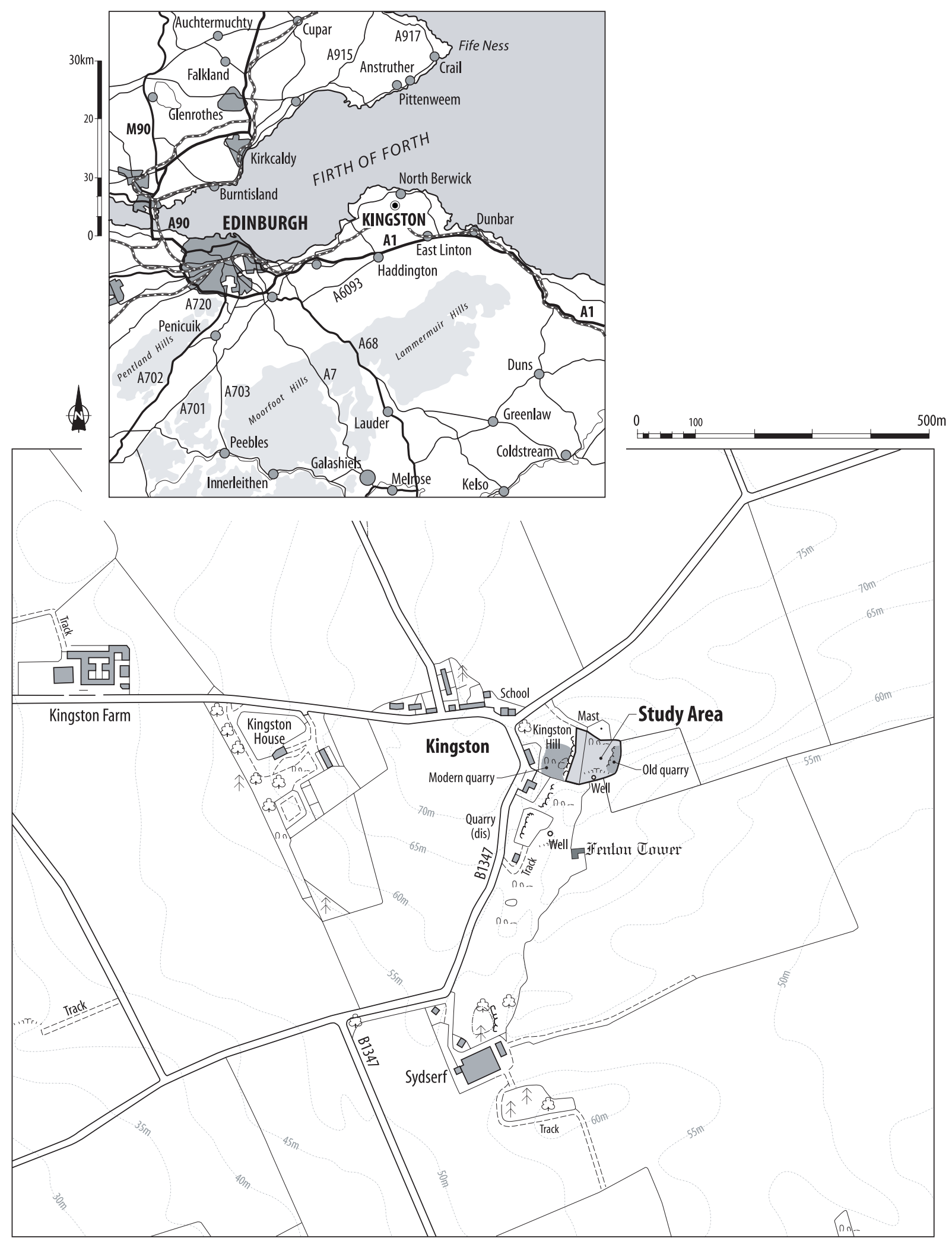

Illus 1 General location map, and the village itself, with the Study Area indicated 


\section{INTRODUCTION}

This report details the results of an archaeological evaluation, commissioned by Historic Scotland and carried out by CFA Archaeology Ltd (CFA) between February and March 2001 at Kingston Common (illus 1-2, plates 1-2), near North Berwick in East Lothian (NGR: NT 544 823). The work was commissioned following the unexpected discovery of human remains by workmen excavating a pipe trench.
The Study Area measures around $2700 \mathrm{~m}^{2}$ and five trenches (illus 3) with a total area of $70 \mathrm{~m}^{2}$ were opened by hand. The excavations revealed a range of archaeological features, including two prehistoric short-cists and thirty-eight early medieval long-cist burials (Suddaby 2001). As the site was not threatened by further development, none of the graves was excavated.

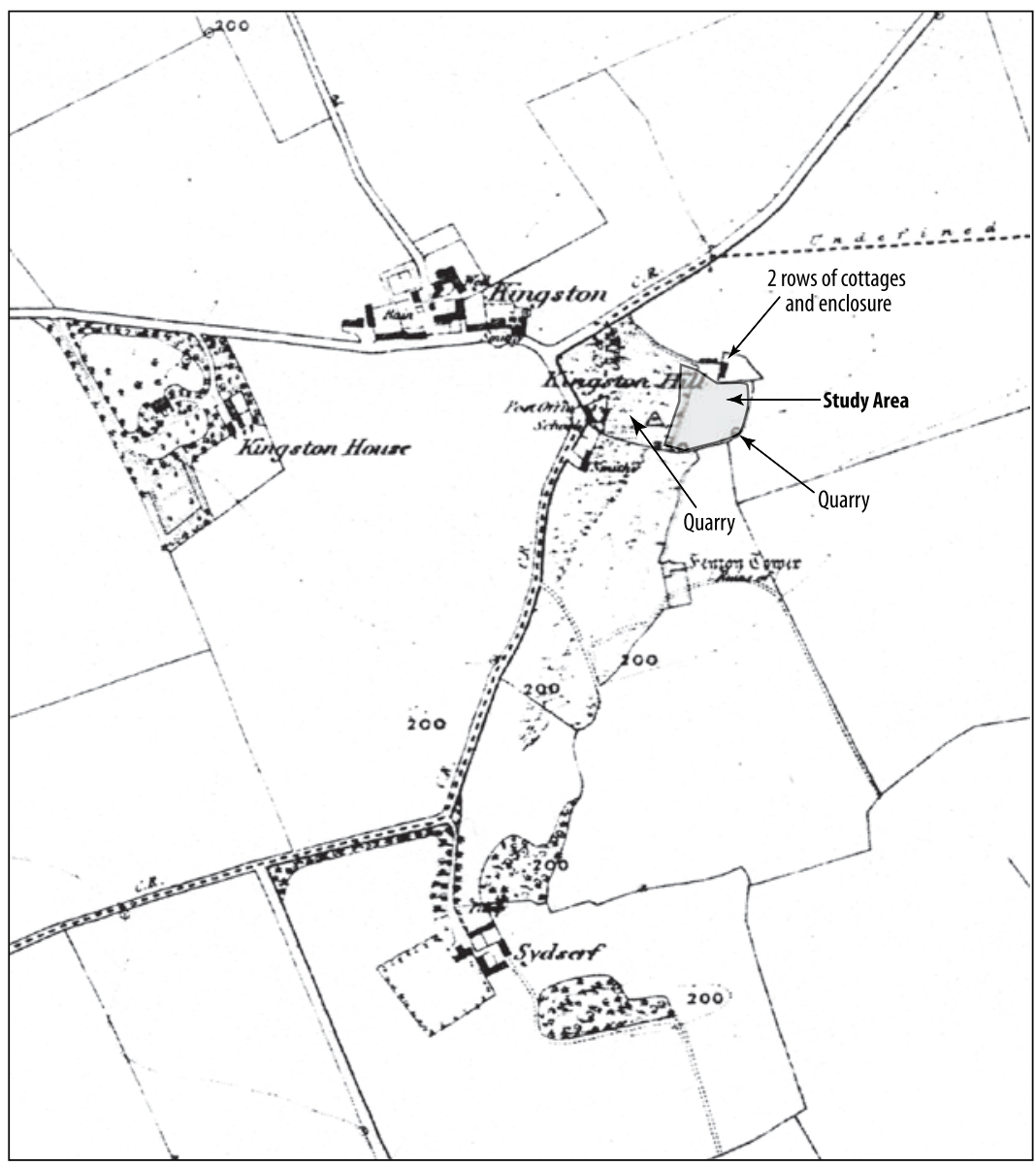

Illus 2 Kingston Hill shown on an extract from the OS 1st

Edition map of 1854 


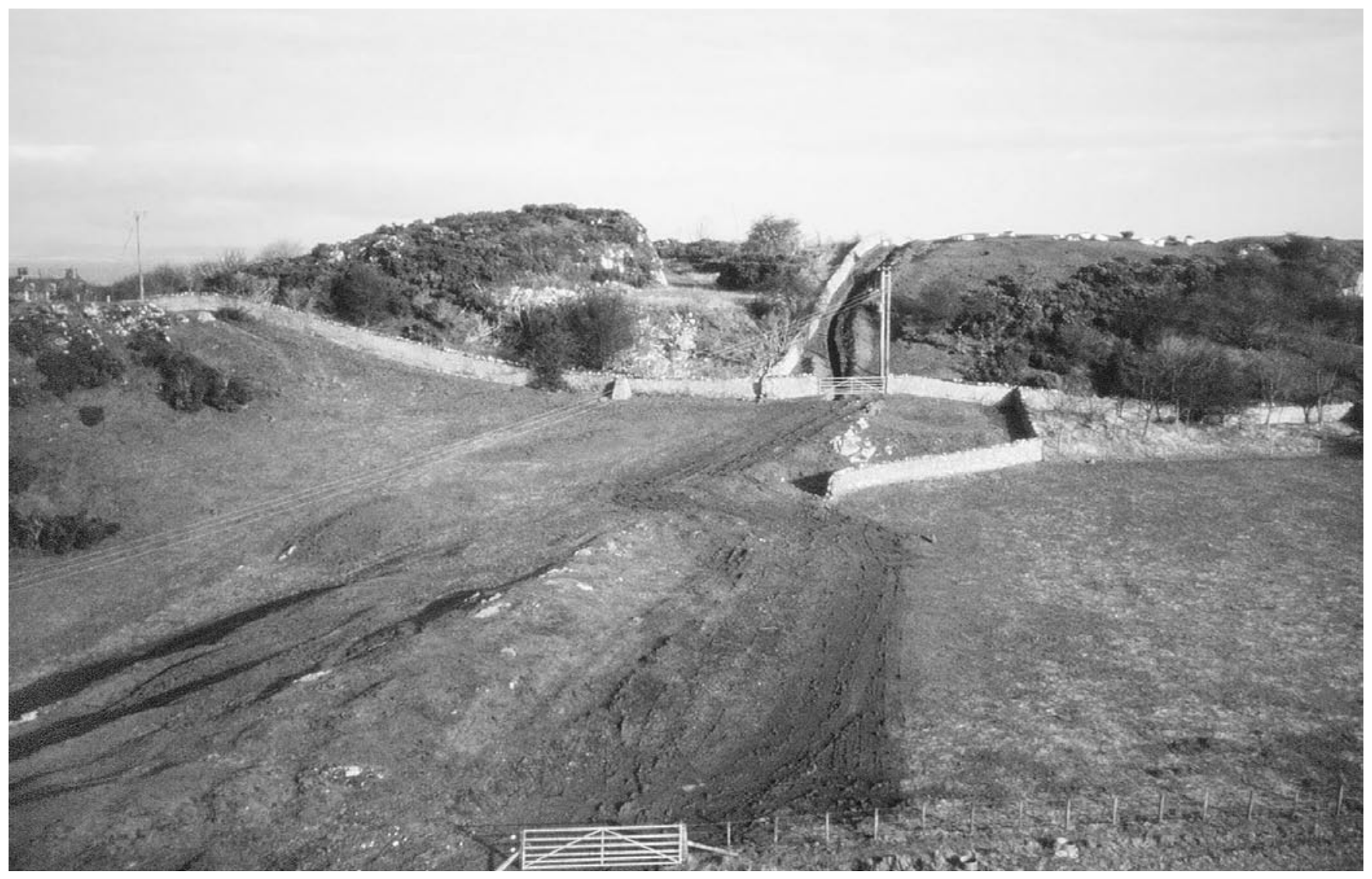

Plate 1 The view from the parapet of Fenton Tower showing the Common on the horizon, with the water pipe trench adjacent to the field wall and the quarry on the left

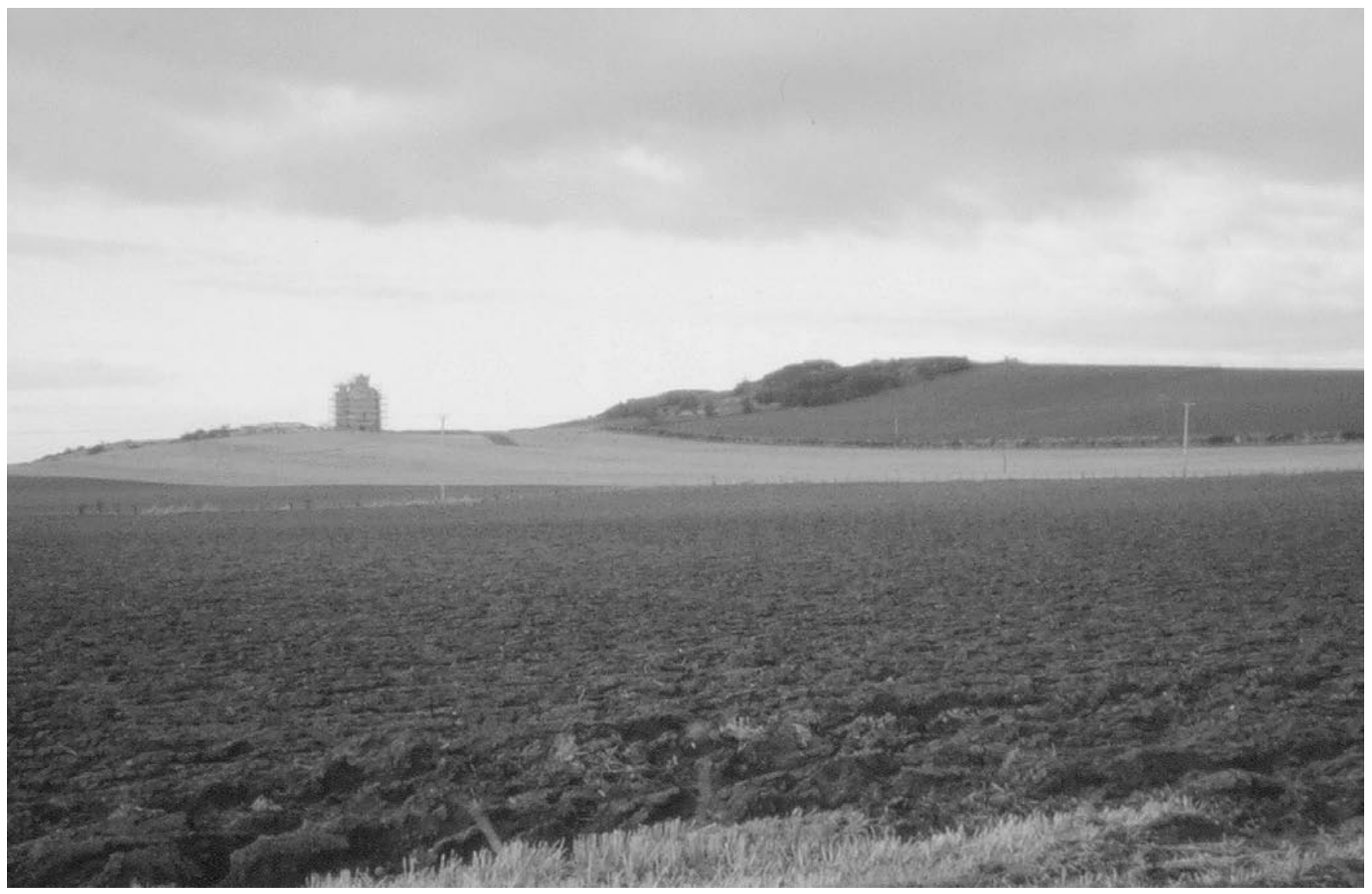

Plate 2 Kingston Common and Fenton Tower, from near Rockwell Farm 


\section{THE EXCAVATION}

All excavated deposits were allocated three-digit context numbers, the first digit of which was the same as the trench number. Features, such as graves and walls, were numbered sequentially and prefixed with a capital F. These numbers are used as appropriate in the following text and in the illustrations.

\subsection{Discovery, aims and methods}

Fenton Tower (National Monuments Record of Scotland (NMRS) No. NT58SW 10) was built in around 1550 by Patrick Whytelaw, son of Lord Ruthven. After long abandonment it has recently been refurbished as a luxury guest house (Country Life 2003). As part of this process, a new water supply was required, which involved laying a pipe from an existing connection at Kingston, over the elongated knoll forming Kingston Common and down to the tower (illus 1 and 3 , plate 1 ). The unsupervised exca- vation of this trench cut through twenty-one burials and only when the work was completed were bones noticed on the spoil heaps. Archaeological assistance was called on by the developers and the police were informed. Once they were satisfied the bones were ancient, the trench sections were cleaned and recorded. Further trenches were then commissioned by Historic Scotland with the aim of establishing the nature and extent of the cemetery on the knoll, with minimal additional damage to the site and without disturbing further human remains, other than to recover samples for radiocarbon dating.

The site is defined to the south by a steep slope and to the west by quarrying. To the north lay the location of 19th-century cottages. The eastern extent was evaluated by Trench 1, with other trenches being placed to answer specific questions posed by the site.

The origin of a cross-carved stone (NT58SW 7, illus 3 , plate 3 ) which is now set into a north-southaligned field wall at the west of the site is uncertain.

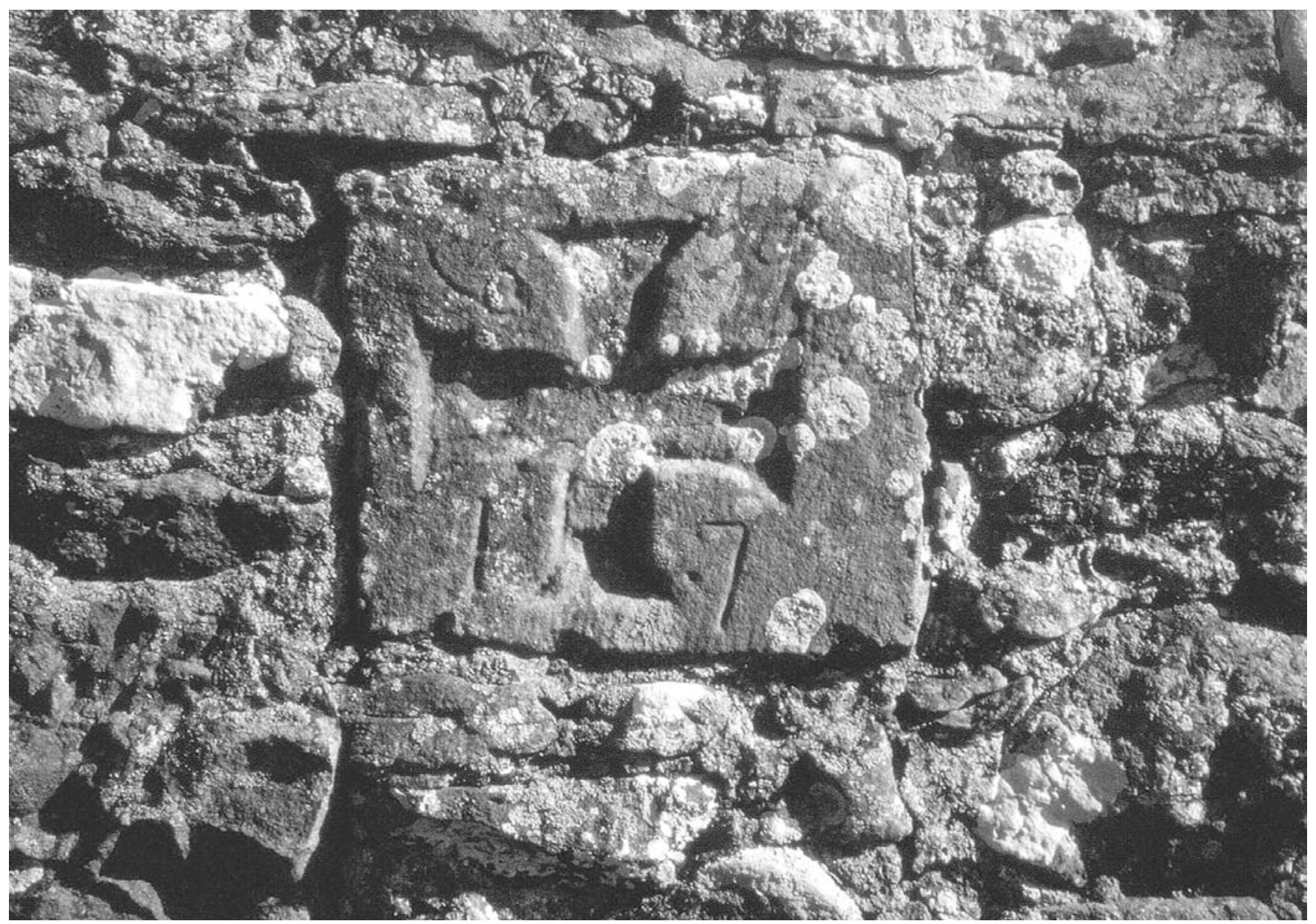

Plate 3 Maltese cross slab set in field wall F24 


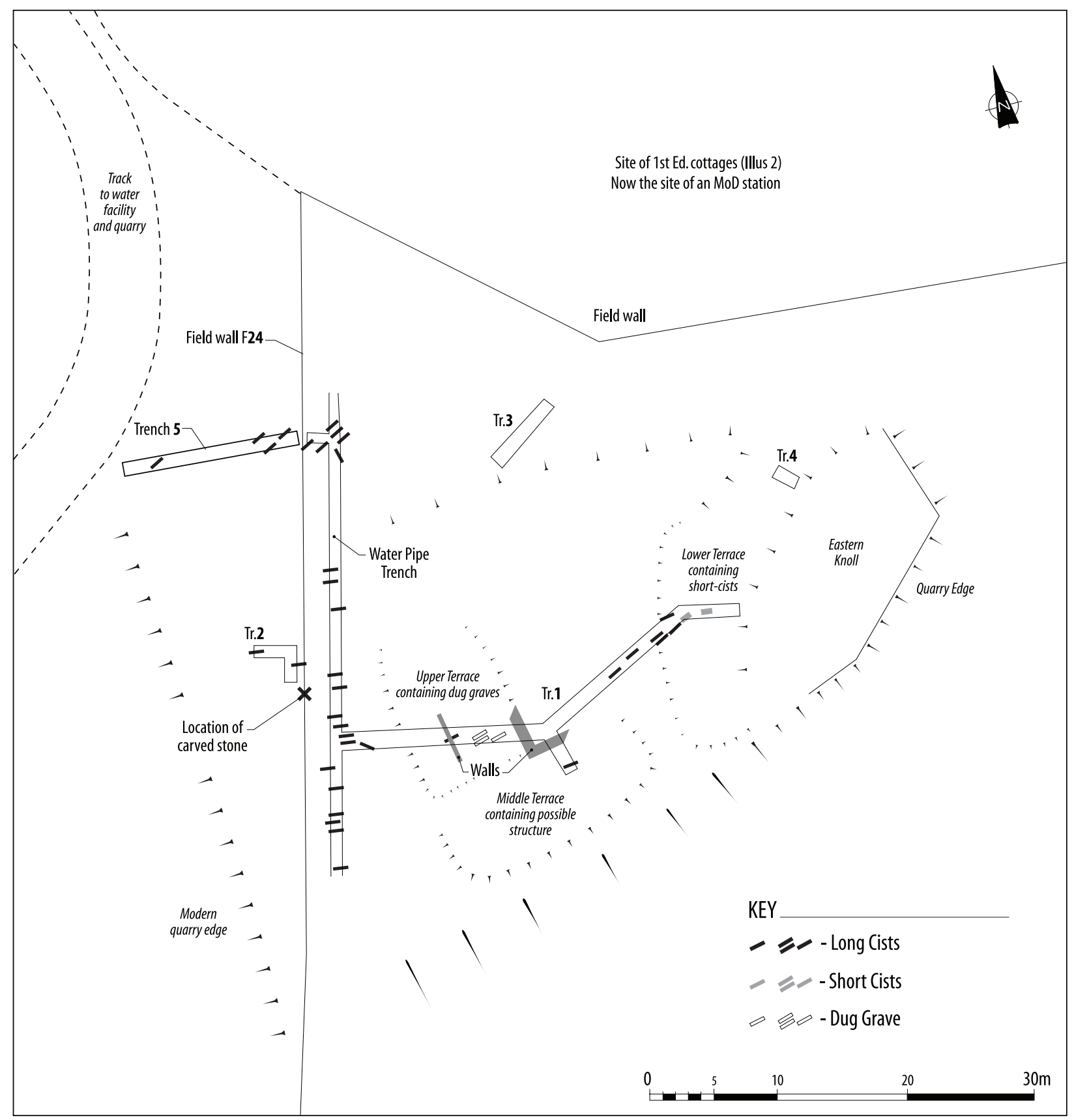

Illus 3 The Study Area, showing trenches, grave types and locations, and the basic topography

Richardson (1906) describes the cross as of 'Maltese' type, with a recessed design and the date ' 1607 '. A feature of the fieldwork was an examination of the role played by the wall (F24), and aimed to establish the relative date of the wall and its relationship, if any, with the graveyard. The conclusions in relation to all aspects of this wall must be qualified, as no detailed search of estate maps or documentary sources has been carried out.

\subsection{Setting}

Kingston Common occupies a low, elongated volcanic ridge (plates 1-2) to the east of the hamlet of Kingston, at around 80m OD. Presently used for pastoral grazing, grass, gorse and patchy exposed bedrock cover the knoll and the area appears never to have been ploughed. Two flat, sub-rectangular terraces defined by slight linear banks are present on the centre of the knoll, and a third lies in a col to the east.

Recent disturbance on the knoll has been very limited, with little apparent from the now vanished cottages to the north of the site. The only recent activities are the placing of a water trough with associated pipe-work next to the field wall and the excavation, probably during WWII, of several foxholes. Bedrock is exposed at several locations but its quality varies widely, from hard and fractured 
outcrops, to soft and rotten material, the latter suitable for the insertion of burials.

The knoll has been quarried to the east and west of the site (illus $1-3$, plate 1 ). The easternmost quarry, not depicted on the maps, is disused, overgrown and obscured by vegetation. The stone extracted from this quarry may have been used in the building of Fenton Tower in the 16th century. The quarry to the west is depicted on the Ordnance Survey 1st Edition map (1854, illus 2) and is currently being in-filled with stones and agricultural waste.

The nearby quarry at East Fenton produces a distinctive yellowish volcanic stone, locally known as 'rattlebag'. Rattlebag was used in the construction of cists F52 and F54. With the possible exception of the short-cists, it appears that no stone from the knoll itself has been utilised for cists, the distinctive and varied geology of the stone from which these had been constructed having been derived from different off-site sources.

\subsection{Background}

The medieval DeVaux family owned the lands of Fenton and around 1290 they built the nearby fortress of Dirleton Castle. The name 'Kyngeston' appears first in the records of Dryburgh Abbey in 1221 and gains occasional mention since then, often in the context of the Hepburns, owners of the tower after it was forfeited by Patrick Whytelaw in 1587. It was abandoned in the 18 th century.

No detailed search has been conducted in order to ascertain the history of the Maltese cross stone. The date and circumstances of its discovery are unknown and Richardson (1906), in recording the stone, gives no assistance in this regard beyond suggesting an origin in a nearby chapel. The motif is the emblem of the Knights Hospitaller, also known as the Order of St John, formed in the 11th century. By the 13th century, it was a common heraldic symbol in Britain (Order of Malta 2008). This Order is recorded as owning land in the area during the 15th century (Cowan et al 1983).

The Ordnance Survey 1st Edition (illus 2) shows two rows of cottages to the north of the Kingston Hill, one of which is set within an irregular enclosure that measures $c 50 \mathrm{~m} \times 30 \mathrm{~m}$. Both rows of cottages had been demolished by the time of the 2 nd Edition in 1894 and most of their area is now the site of an abandoned Ministry of Defence facility.

\subsection{Excavation results}

\subsubsection{Trench 1}

This trench was positioned to evaluate the terraces, defined by low banks, to the east of the water pipe trench, running from just east of wall F24 up to a prominent knoll of bedrock at the east of the site (illus 3-4). The trench contained two short-cists
(F40, F41), some evidence for a building (F32), probable long-cists (F6-7, F25, F28, F34-9, F50) and dug burials (F11, F45). It also contained a possible cobbled surface (F33) to the north of F32 and what may be a post-hole (F26). The turfy topsoil (101-4) had an average depth of $0.15 \mathrm{~m}$; it overlay archaeological remains and contained pottery from three periods: prehistoric, 12th-14th centuries $\mathrm{AD}$ and late 18th-20th centuries $\mathrm{AD}$. Bedrock was seen in the centre of the trench but over most of the area, archaeological remains obscured natural deposits.

The earliest features were the two short-cists near the eastern end of the trench (plate 4). Both were found below a homogeneous, friable, buried soil deposit (112). The short-cists had apparently been cut from the base of this layer. Context 112 is interpreted as representing the natural build-up of soil in a sheltered location, perhaps initially augmented by imported material to cover the graves. This deposit contained chipped stone (Warren below), coarse stone tools (Jackson below), abraded Impressed Ware pottery (MacSween below) and animal teeth. Assuming it is not re-deposited, the presence of this pottery assists in the dating only inasmuch as it appears to rule out cist construction in the Iron Age, as Impressed Wares span the period from the

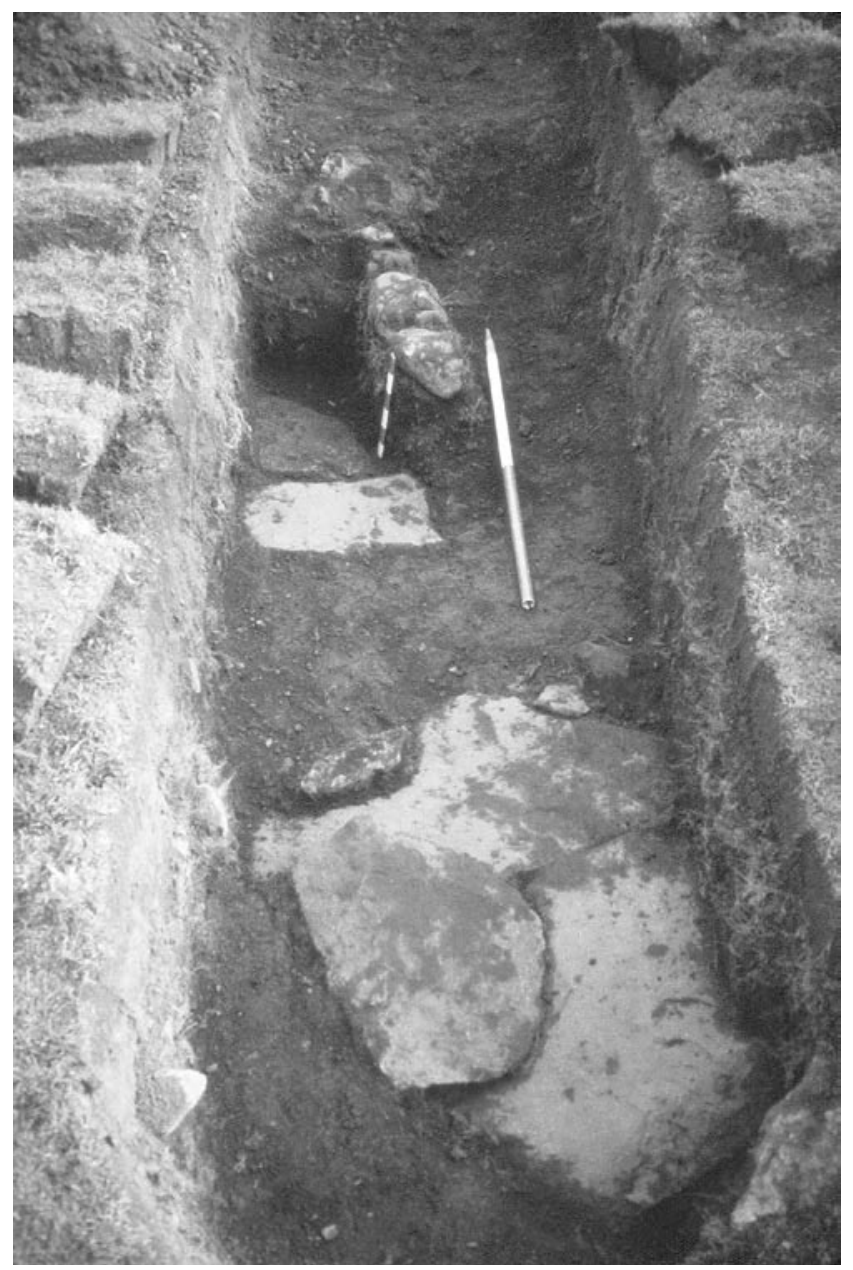

Plate 4 Trench 1, short-cists F40, F41 from north-west 


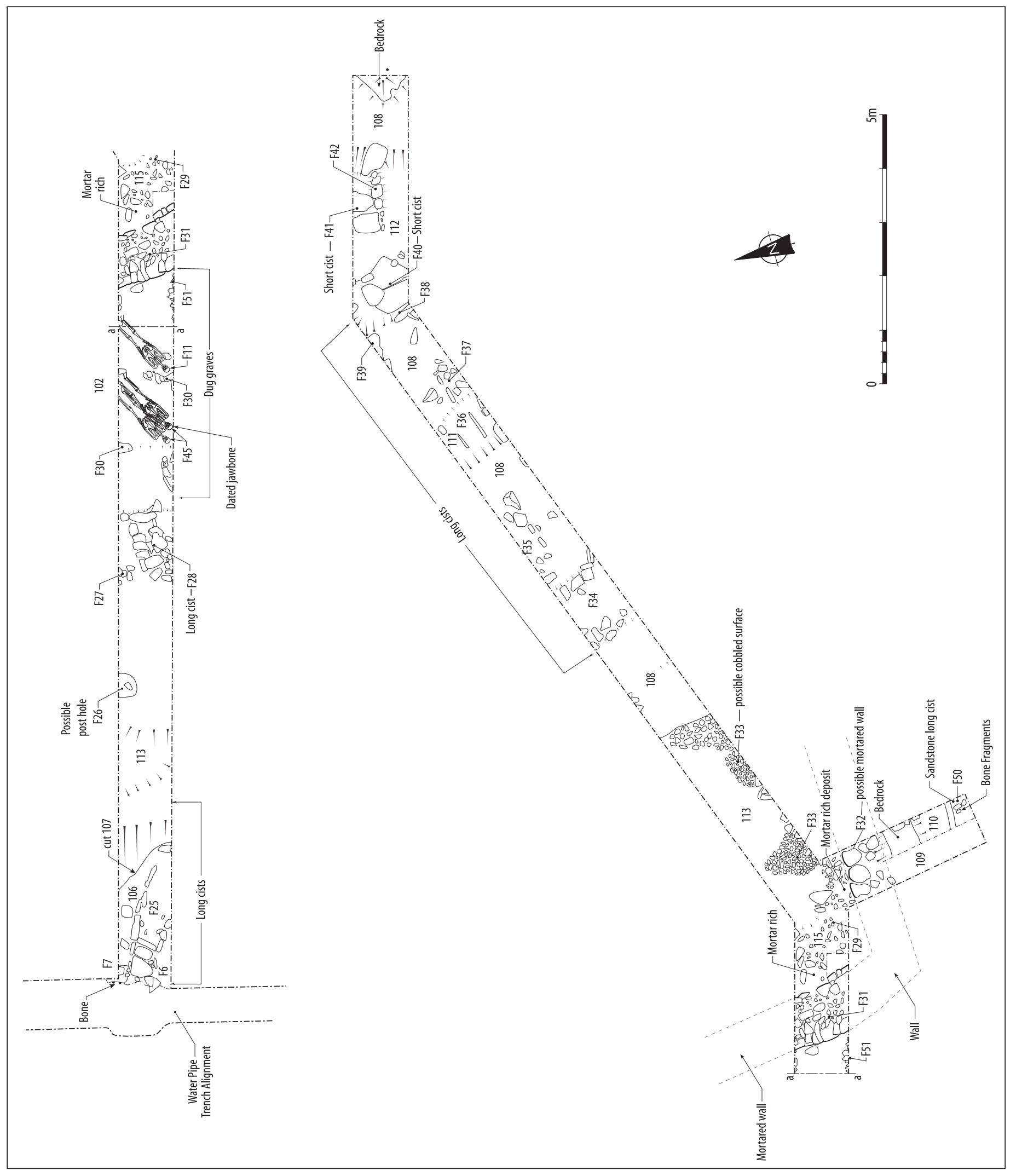


later fourth millennium to the mid third millennium BC. Neither cist was opened and recording was restricted to descriptions and a plan drawing. The smaller of the cists (F40) was not fully exposed in the confines of the trench but measured $0.7 \mathrm{~m} \times$ $0.5 \mathrm{~m}$ and was aligned close to east-west. The larger cist (F41) measured $1.1 \mathrm{~m} \times 0.9 \mathrm{~m}$ and was also aligned roughly east-west. Both were constructed from an almost black volcanic rock, probably basalt. This type was not otherwise recorded in graves on Kingston Common but was not dissimilar from some of the bedrock revealed in the quarry.

Overlying the buried soil 112 was a thin deposit of reddish-purple volcanic stone chips (108) containing medieval and prehistoric pottery. This probably relates to digging activity associated with the longcists to the west.

The long-cists were distributed in three locations within the trench. One concentration was found to the east of the terraces, a second to the west of the terraces, with the third being represented by a single grave on the Middle Terrace in the southern trench extension, underlying the suggested location of the chapel. Further examination of this distribution with reference to the constructional geology is informative. To the north-east of F32 was an area of cobbles and all of the long-cists to the east (F349) were lintelled and constructed from the same reddish-purple volcanic stone noted in layer 108. Those to the west of the terraces (F6-7, F9, F14, F25, F28) were, with the exception of F25, formed from the same material and the existence of shared capstones in some instances suggests they are either contemporary or very similar in date. Where undamaged, these long-cists were associated with overlapping, often irregular, lintels of identical rock. F28 was less than $1.5 \mathrm{~m}$ in overall length and may be a child's grave. The long-cist (F50) in the southern extension to the trench (illus 3-5) was, with F25 (and F44 in Trench 2), of different construction and contrasting geology from those described above. These cists were formed from regular sizes of yellow or red sandstone, without lintels. An iron nail recovered from the surface of F25 during cleaning may suggest the presence of wooden coffins in these instances.

Long-cist F50 was sealed (illus 5) below a rich, dark brown soil (110) which was itself below a layer of gravelly sand and silt (109) containing 12th-century pottery. This lay below a thin possible destruction layer (105) comprising stone chips and flecks of charcoal in a sandy matrix. Both 12thand 19th-century pottery were recovered from this layer. Deposits 105 and 109 abutted a low, east-west alignment of volcanic boulders (F32) with a length of $5 \mathrm{~m}$. This wall would, on surface evidence, be associated with the north-south mortared wall (F31) and its parallel boulder alignment (F27), which defined the eastern and western sides of the Upper Terrace (illus 3-4). Although inconclusive, the evidence may point to the existence of a small structure on the Middle Terrace, possibly an early chapel, destroyed in the 19th century.

Within the $12 \mathrm{~m} \times 5 \mathrm{~m}$ area enclosed by F27 and F31, were two parallel north-south-aligned stone rows (F30), formed from large cobbles. Laid obliquely between these rows were a series of closely spaced dug graves, including F11 and F45, aligned north-east to south-west, with the heads at the south-west. A radiocarbon determination from a mandible recovered from F45 (Table 1) indicates burials were taking place here in a period centred on the 11th century $\mathrm{AD}$.

Little stratigraphic information was forthcoming from this trench. To the east, deposits (108) associated with the long-cists overlay one associated with the short-cists (112). On the middle terrace, deposits associated with the possible structure (105, 109) overlay a soil (110) which sealed a sandstone long-cist (F50). To the west of the terraces, longcists of volcanic stone appeared to be squeezed in, avoiding the sandstone long-cist that may therefore be of earlier date. The clear impression is that the possible structure is associated with the enclosure to the north and the dug burials, rather than the long-cists.

\subsubsection{Trench 2}

Trench 2 (illus 3, 6 and 7) was excavated to the west of the field wall (F24), close to the location of the Maltese cross slab. It aimed to assess the western extent of the cemetery and any relationship to the field wall itself. Two burials (F43, F44) were revealed to underlie the mortar-flecked topsoil (201), a notably lower density than that in the water pipe trench, located $c 3 \mathrm{~m}$ to the east. F44 was formed from red sandstone side slabs and had no capstones. It ran under the field wall (F24, plate 5), being separated from it by $0.2 \mathrm{~m}$ of topsoil (201). There was no impression of capstones having being disturbed by the building of the wall and it is likely that, as with other sandstone-constructed long-cists at Kingston, they were never present. The second burial (F43) was formed from reddish volcanic stones with overlapping lintels. Both burials were aligned close to east-west. A single sherd of unglazed medieval pottery was recovered from the topsoil (201).

\subsubsection{Trench 3}

Trench 3 (illus 3 ) was located to the north of the knoll and aimed to ascertain the presence of burials away 
a)
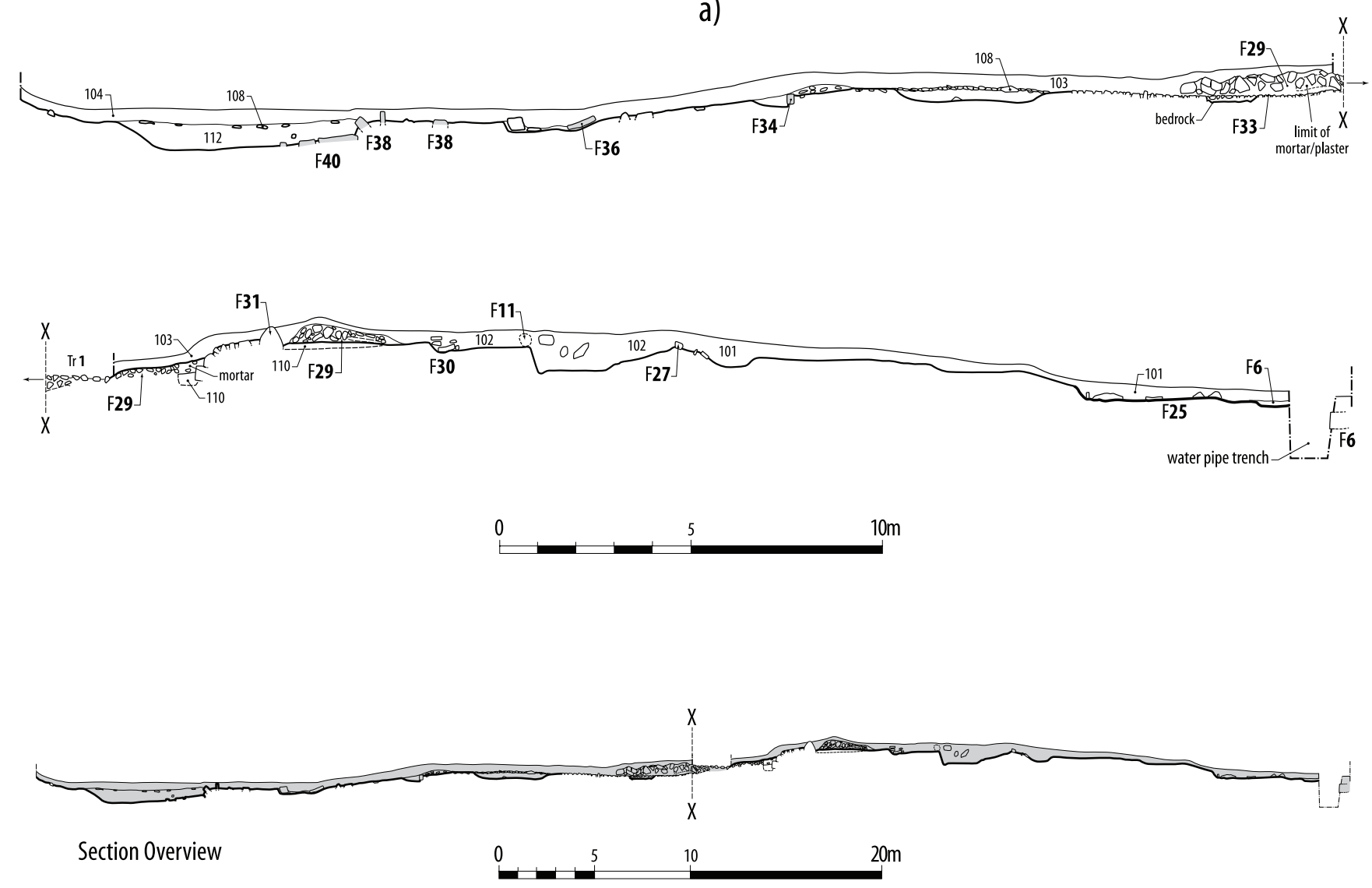

b)
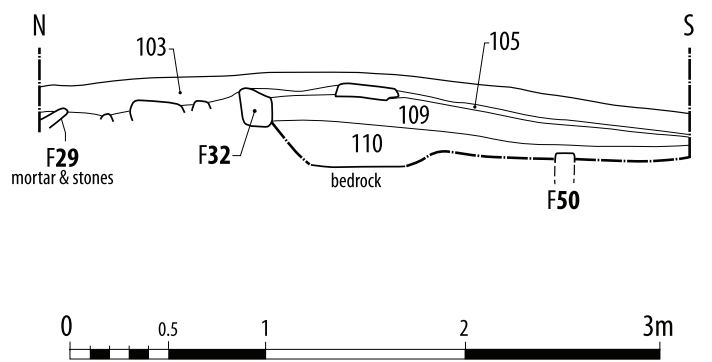

Illus 5 Trench 1, north-facing section (a), including the west-facing section in the trench extension to the south (b)

from the bedrock-defined knoll and to explore the site of the cottages on the OS map of 1854. Numerous artefacts dating to the 18th-19th centuries were recovered from the rich, dark brown topsoil (301), but no structural remains were revealed and there were no burials. The topsoil overlay smooth and very hard volcanic bedrock.

\subsubsection{Trench 4}

This trench (illus 3) was positioned within a gully leading up onto the knoll from the north-east. This is presently the easiest approach to the summit plateau, and may once have been a formal trackway. Under the turf was a thin red-brown clay-silt topsoil, 


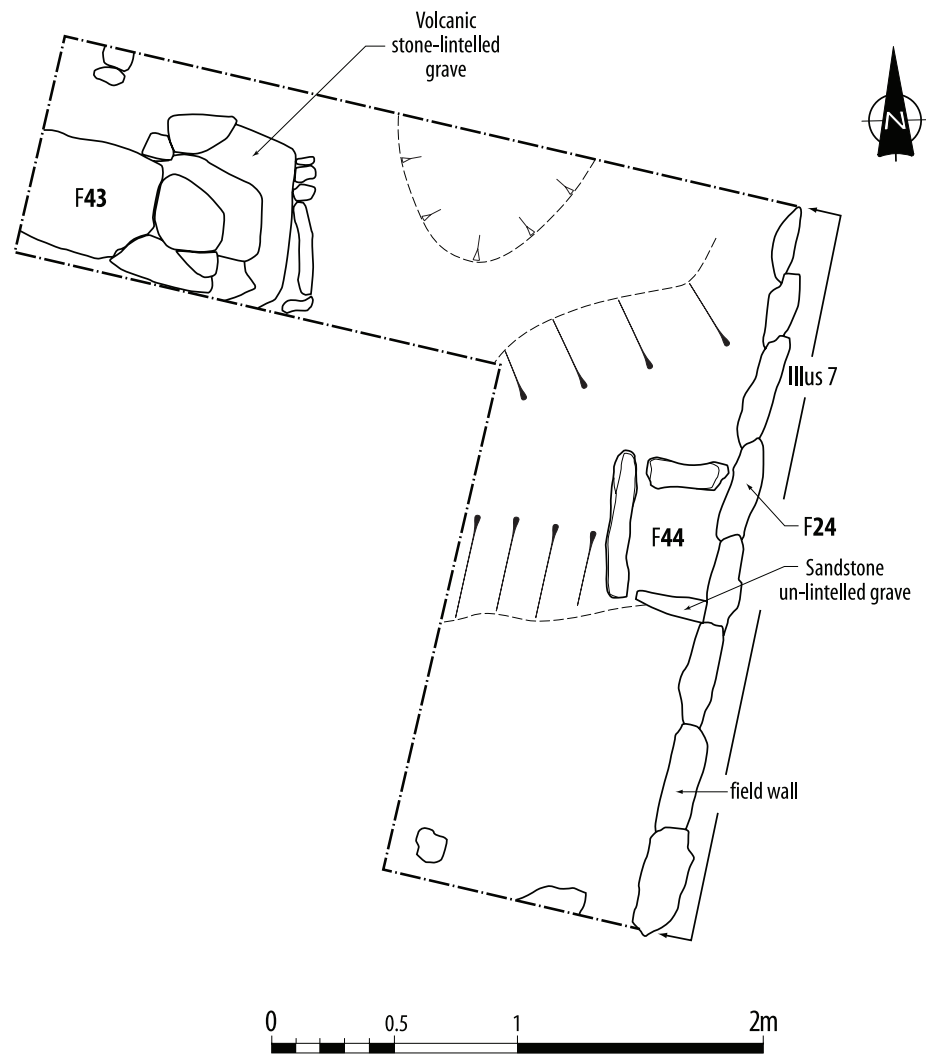

Illus 6 Trench 2, plan showing lintelled long-cist F43 and the un-lintelled long-cist F44 underlying field wall F24
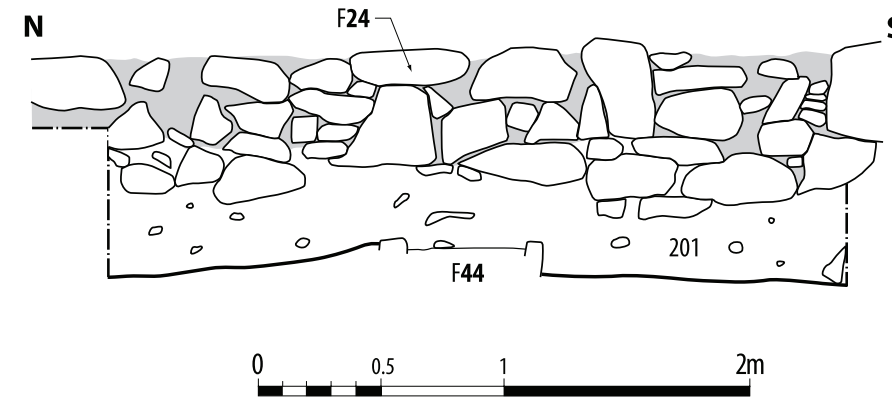

Illus 7 Trench 2, west-facing section showing long-cist F44 underlying field wall F24

below which was stony subsoil. There were no traces of a cobbled surface or of wheel ruts and no artefacts were recovered.

\subsubsection{Trench 5}

This trench (illus 3, 8 and 9) lay to the west of the field wall and was located $18 \mathrm{~m}$ to the north of Trench 2. It was excavated along the line of the new water pipe from the machine-excavated water pipe trench to its junction with the existing water supply network.

Excavation revealed a thin and almost sterile topsoil (501) that overlay a deeper buried soil (502) that contained 18th- and 19th-century artefacts. This soil in turn overlay a lens of mortar (503) at the base of the wall. Below 502 was a homogeneous soil deposit (504) from which four sherds of medieval pottery were recovered. This deposit sealed four well-preserved long-cists (F52-5) and the sequence is reminiscent of that in the southern extension to Trench $1(105,109-10)$. The capstones of F53 in the east of the trench, close to the wall, were $0.8 \mathrm{~m}$ below the present ground surface, whereas those of F55 in the west of the trench had a depth of only $0.2 \mathrm{~m}$. All four long-cists had capstones and all were predominantly constructed from reddish volcanic rock, 


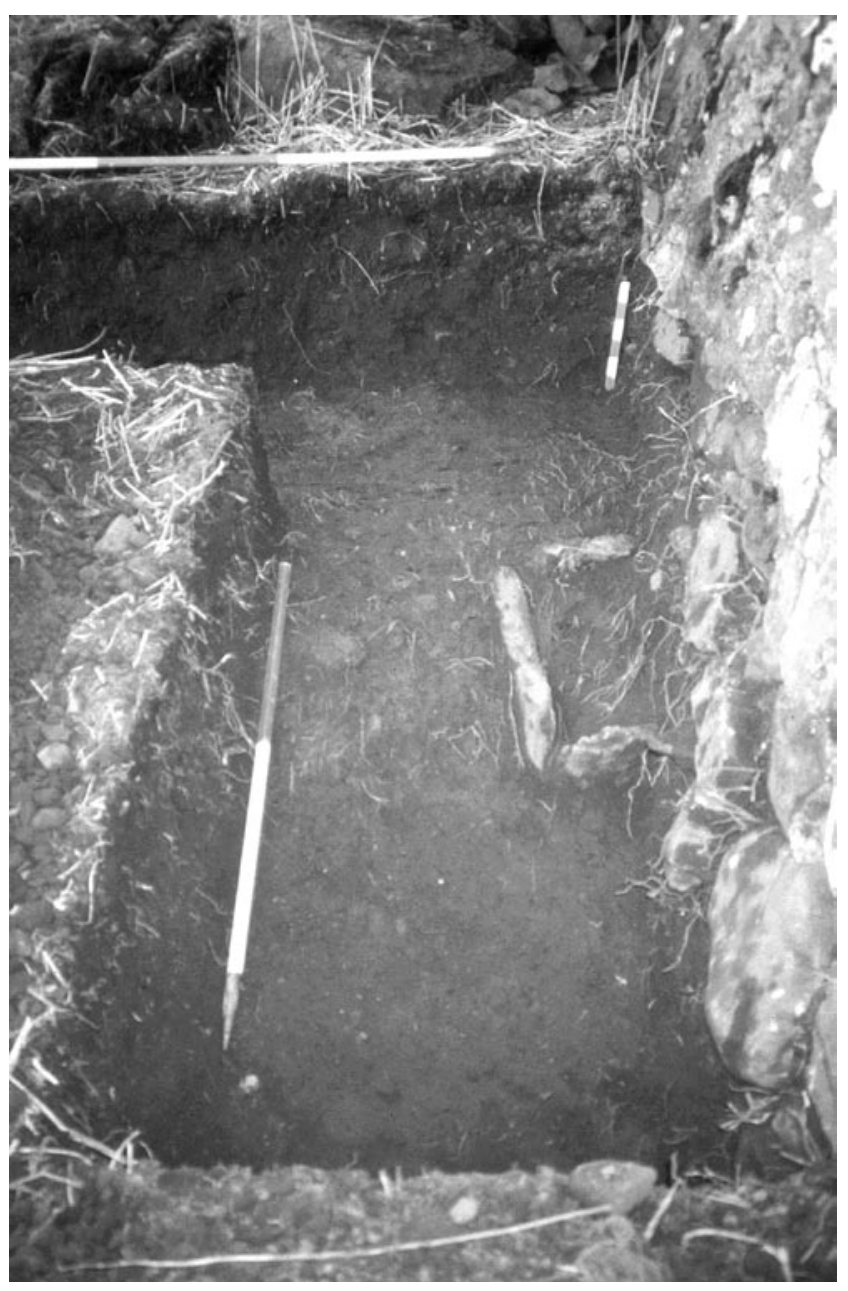

Plate 5 Trench 2, long-cist F44 underlying wall F24

although F52 and F54 included yellow volcanic rock (rattlebag) in their structure.

\subsubsection{Water pipe trench}

This trench (illus 3,10 , plate 1 ) was excavated by machine to a depth of around $1 \mathrm{~m}$ over the summit of the knoll without archaeological supervision. It ran roughly parallel to the field wall (F24), through a slight col or gully in the uneven summit area and encountered much rotten bedrock. Only after the excavation was completed were bones seen on the spoil heap. Archaeological work was restricted to cleaning and recording both long sections (illus 10) and recovering a bone sample from one of the cists (F7, Table 1) for radiocarbon dating.

Twenty-one burials, all long-cists and all aligned close to east-west, were recorded. They extended over a $35 \mathrm{~m}$ length of the trench and were not confined to the summit of the knoll. A notable cluster (F20-23, F46-7) was present below the scarp defining the north of the knoll, at a point where glacial drift deposits underlay the topsoil. No features were present to the north of this cluster but it is uncertain whether this indicates the location of the cemetery's northern boundary, as any earlier remains may have been removed by constructing the cottages that once stood in the vicinity. On the summit of the knoll, two long-cists (F17, F18) had been cut into the rotten bedrock, with F17 appearing to post-date F18. To the south of these, at the west end of Trench 1, several graves (F1-9, F14, F48-9) had been excavated through drift deposits similar to those noted to the north.

Despite a careful search of the spoil heaps, no artefacts were found that could be interpreted as representing grave goods. The damaged graves may all be interpreted as early medieval long-cists.

\subsection{Coarse stone, by Adam Jackson}

Five coarse stone tools were collected. One came from the topsoil (104) and three from the buried soil (112) in the east of Trench 1, with one being a surface find to the west of wall F24. All five comprise waterrounded cobbles of sandstone, granite or chert and show no other modification than that resulting from use.

The four recovered from the east of Trench 1 appear to have been used as hammerstones and/or
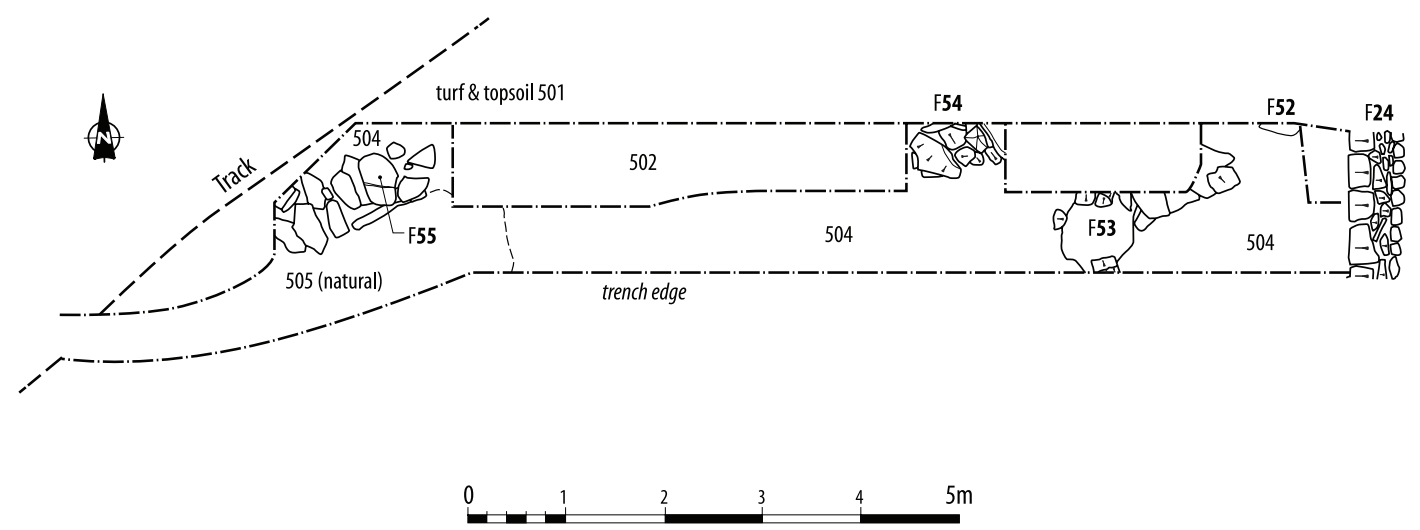

Illus 8 Trench 5, plan showing long-cists F52-5, all formed from volcanic stone 


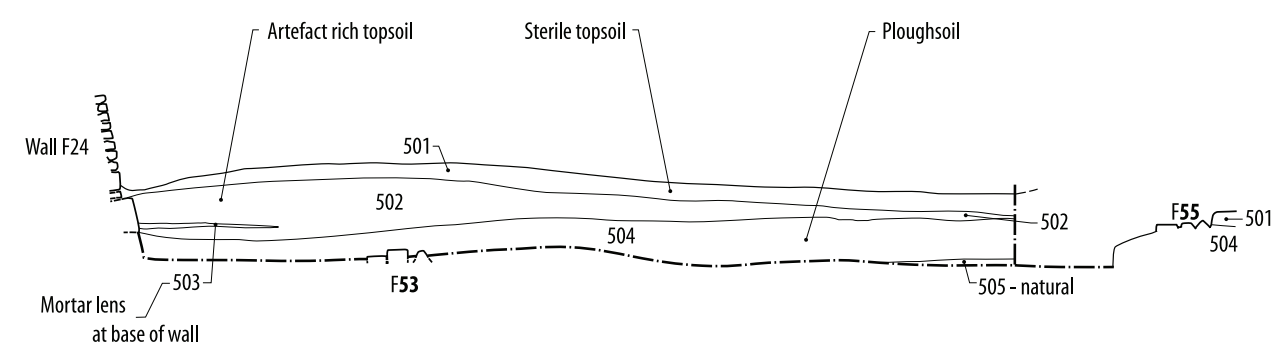

at base of wall

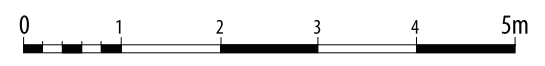

Illus 9 Trench 5 north-facing section showing soil layers over long-cists
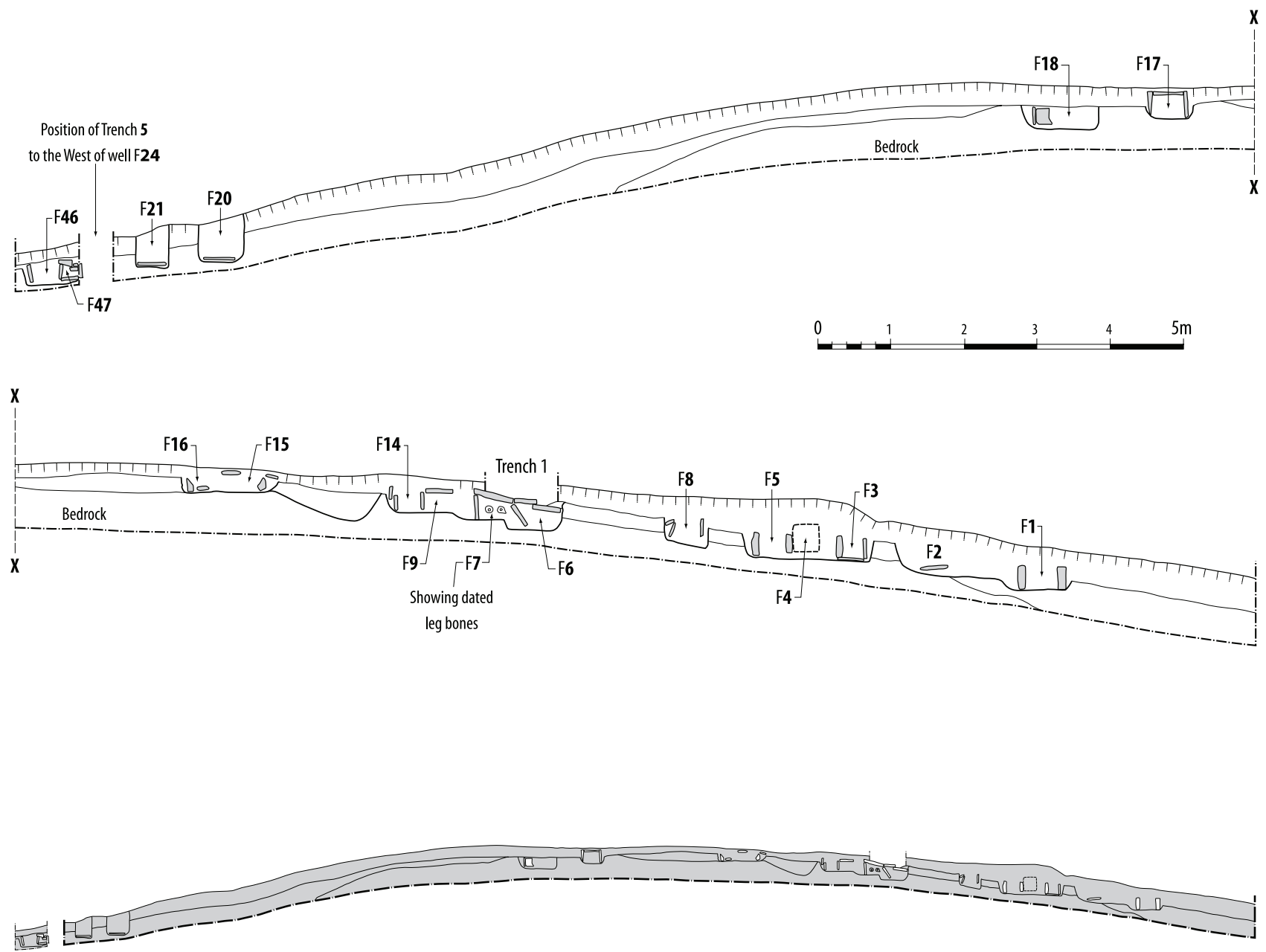

Section Overview

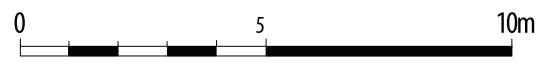

Illus 10 Water pipe trench, west-facing section

grinders. Given their essentially natural form and expedient function it is not possible to date these artefacts on typological grounds. The surface find shows evidence of use as both a general grinding tool and a whetstone. This latter function is suggested by a number of $\mathrm{V}$-shaped grooves on the main work surface that are likely to have been the result of the stone being drawn repeatedly along the blade edge, which is consistent with the medieval or modern date suggested by the pottery from the site. 


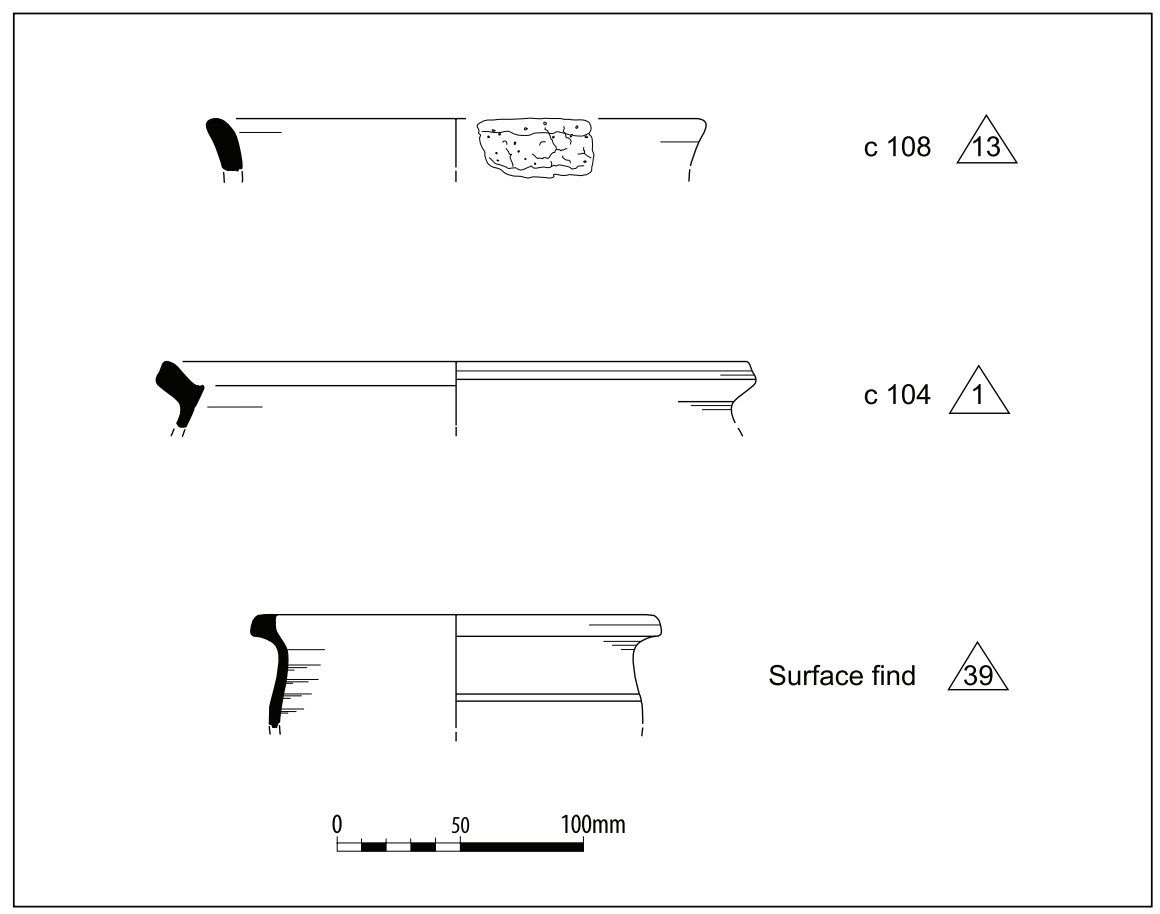

Illus 11 Prehistoric (SF 13) and White Gritty Ware (SFs 1 and 39) pottery

\subsection{Chipped stone, by Graeme Warren}

Five lithic artefacts were recovered but were nondiagnostic in terms of formal type or technological affiliation. One of these artefacts was recovered from the water pipe trench spoil heap. It is bladelike in form but was not made using a dedicated blade-production technique. The discovery of a single scraper does not provide enough evidence for the date or function of the site.

\subsection{Prehistoric pottery, by Ann MacSween}

Three sherds of pottery were recovered from the east of Trench 1 at Kingston Common. They were found in a buried soil horizon (112) and a lens of stone chips (108, illus 11). Both contexts overlay a pair of short-cists and 112 also contained chipped stone tools and hammer stones.

While the level of abrasion makes identification difficult, it is probable that these are Neolithic Impressed Wares. This type of pottery, also known as 'Scottish Impressed Wares' (McInnes 1964) and 'later Neolithic decorated wares' (Kinnes 1985), is found widely in Scotland. Many of the Impressed Ware assemblages have been recovered from coastal and dune sites which have little structural association. Examples include Hedderwick, East Lothian (Callander 1929) and Brackmont Farm and Tentsmuir, Fife (Longworth 1967). When Impressed Wares are found in an archaeological context, they are most often found in a pit, as for example at Brackmont Mill (ibid, 72) and Grandtully, both in Perthshire (Simpson \& Coles 1990).
Impressed Wares have traditionally been regarded as 'late Neolithic', although Sheridan (1997) suggested that dates in the mid to late fourth millennium BC should not be discounted. The dating of the Impressed Ware from Blairhall Burn, Dumfriesshire (Strachan et al 1998, 73) indicates a date in the second half of the fourth millennium BC. Most recently, Impressed Ware from the cemetery at Eweford in East Lothian (Lelong \& MacGregor forthcoming) has been dated to 3500-2900 cal BC.

\subsection{Medieval and later ceramics, by John Lawson}

\subsubsection{Introduction}

The excavation produced a total of 83 sherds of medieval and recent (late 18th-20th-century) date. All were examined by eye and, where possible, assigned a recognised fabric name. No petrological analyses were undertaken.

\subsubsection{Medieval}

Nineteen sherds of the medieval Scottish White Gritty Ware (SWGW) were recorded. This fabric type is common throughout eastern and central Scotland between the 12th and 15th centuries. Although only one kiln site has so far been identified (at Coulstoun, East Lothian), the Scottish White Gritty Ware Project (Jones et al 2006) has demonstrated that this ware was produced widely at a local level.

The majority of the sherds derive from small cooking pots or jars that date to the mid 12th-13th 
centuries, with only three sherds (SF17, 31,33) being identified as being 13th-14th-century in date. Three sherds came from straight-sided cooking vessels dating to the mid to late 12th century (illus 11), the earliest recognised form of this fabric.

Eight of the sherds were found to the west of wall F24, four from a buried soil (504) over long-cists F52-5 and four were surface finds in the nettles and rabbit burrows just west of Trench 2 . These were all unglazed. One sherd was found in Trench 2 topsoil (201) and seven were found in the Trench 1 topsoil (101, 103-4). They therefore derive from all parts of the trench except the upper terrace (102) where the dug graves were recorded. Three sherds were recovered from the southern extension of Trench 1 on the middle terrace $(105,109)$. A single sherd was found on the water pipe trench spoil heap.

\subsubsection{Modern}

The majority of the assemblage (64 sherds) is a mixture of the common domestic pottery fabrics of the late 18 th and 19 th centuries, including both white and red glazed earthenwares, industrial stoneware and transfer-printed and sponge-decorated white earthenwares. With the exception of a mid 18thcentury sherd from a moulded salt-glazed plate (possibly made at Prestonpans, $c$ 1750-70), the majority of the identified material falls within a date range of between $c 1810$ and 1840 .

\subsubsection{Discussion}

Although small, the excavated assemblage has proved to be of interest, with two distinct groups of material recovered, separated in date by 400 years.

The later 12th-century date for the earliest SWGW sherds is supported by the radiocarbon date from F45, which demonstrates that burials were taking place around, or slightly before that time. The distribution of medieval ceramics is uninformative, although all of the glazed medieval pottery was found to the east of the wall.

It is also notable that the construction of Fenton Tower in around 1550 and its occupation until the mid 18th century coincides with a hiatus in the pottery record on Kingston Common.

The date range ascribed to the modern ceramics supports the cartographic evidence in that it suggests occupation, concentrated to the north of the knoll, from the early 19th century until the late 19 th or early 20 th centuries.

\subsection{Skeletal remains, by Paul Duffy}

\subsubsection{Introduction}

Specialist analysis was undertaken of the small assemblage of disarticulated remains collected from the spoil heaps along the water pipe trench, from topsoil in Trench 1, and from two of the graves (F7 and F45), sampled to provide material for radiocarbon dating. The assemblage comprised the remains of a minimum of seven individuals, identified through repeated skeletal elements. Ageing and sexing demographics were limited but suggest a population of largely mature adults, with three males and four females. A number of skeletal pathologies were identified, including an unusual healed fracture of a lumbar vertebra.

The preservation condition of the bone was, in general, fair, based on the surface erosion and fragmentation of the individual elements. A number of intact or partially intact skeletal elements were present. Most of these displayed a high degree of surface erosion, possibly due to burial conditions or to post-exposure weathering.

\subsubsection{Methodology}

An inventory of all the skeletal elements was made. The minimum number of individuals was determined by recording any repeated skeletal elements, or elements from individuals of clearly different biological age. The methods used to determine age at death and sex were in accordance with those outlined by Buikstra \& Ubelaker (1994). There were no intact long bones present from which to calculate living stature.

\subsubsection{Results}

Trench 1 topsoil (102)

Fourteen bones and seven bone fragments were recovered from the topsoil (102) within the possible burial plot on the upper terrace. The minimum number of individuals identified was, based on repeated skeletal elements, one. However, the size and morphological appearance of the skeletal elements from this context suggest that at least two adult individuals were represented, a male and a female.

\section{Dug Grave F45}

A sample of skeletal material was recovered for the purposes of radiocarbon dating. The sample consists of a mandible (lower jaw) and the left posterior portion of the maxilla (upper jaw), from a single individual. The morphology of these elements strongly suggests a male, and dental attrition (Brothwell 1965) indicates an age of between 35 and 45 years.

The individual suffered from moderate dental disease, with severe to moderate periodontal disease noted on the mandibular alveolar process, and slight periodontal disease on the maxillary alveolar process. Periodontal disease is a general term used to describe the inflammatory changes that can occur in the soft tissues and bone around a tooth in response 
Table 1 Radiocarbon dates from Graves F7 and F45

\begin{tabular}{llllll}
\hline Feature & Lab No & Radiocarbon Age & $\delta^{13} \mathbf{C}$ & \multicolumn{2}{c}{ Calibrated Age Ranges } \\
& & & & 1-sigma & 2-sigma \\
\hline F7 (long-cist) & GU-11057 & $1395 \pm 45$ & $-21 \% 0$ & $620-665 \mathrm{AD}$ & $585-680 \mathrm{AD}$ \\
F45 (dug burial) & GU-11068 & $1010 \pm 50$ & $-20.3 \%$ & $970-1150 \mathrm{AD}$ & $890-1160 \mathrm{AD}$ \\
\hline
\end{tabular}

to plaque (Ortner and Putschar 1981), resulting in inflammation and resorption of the underlying bone. The most common cause is poor oral hygiene. The teeth of this individual also showed considerable wear, particularly on the first molars, which are the earliest of the molar teeth to erupt.

\section{Long-cist F7}

The elements in the sample from F7 represent a single individual from a long-cist, recovered for radiocarbon dating purposes. The sample consists of portions of two adult femurs, possibly female, and the acetabulum area of the left innominate (pelvic bones). All elements were fused and of adult size, but no further ageing indicators were present.

\section{Water Pipe Trench Spoil Heap}

This assemblage of material represents disarticulated skeletal elements recovered from the spoil heaps following the initial excavation of the pipe trench.

The minimum number of individuals identified in the assemblage was four, based on repeated elements of the ulna and morphological characteristics of the skeletal elements examined. The majority of elements present within the assemblage did not display sufficient sexually dimorphic traits to allow sex to be identified. However, a minimum of two females and one male were found to be present.

A rare shear fracture of the spinous process of the first or second lumbar vertebra was noted. The vertebra had fractures at the top of the spinous process, and was well healed, although the callus was still visible. The fracture had resulted in the displacement of the spinous process anteriorly and medially on the right side, resulting in hypertrophy (enlargement) and remodelling of the left inferior process and remodelling and osteophyte formation on the right articular process, with extension of the articular surface. The fracture is associated with hyperextension of the back, and is likely to be activity related, rather than related to traumatic injury (Galloway 1999). Untreated, it is likely to have caused posture alteration and extreme discomfort to the individual.

A second vertebra from this assemblage also showed remodelling changes of the right superior process, with hypertrophy, pitting and osteophyte formation of the articular surface characteristic of osteoarthritis. Whilst the two vertebrae did not articulate directly, it is possible that these changes resulted from the fracture described above, as a result of altered posture of the individual.

\subsubsection{Conclusions}

A minimum of seven individuals was identified. Although sexually dimorphic elements were few, male and female elements were represented in roughly equal proportions. The majority of the individuals were adults, and although some young adults were represented, only one definite juvenile element was present. Given the relatively small sample area and the conditions of recovery, it is unlikely that this reflects the true demographic profile of the cemetery as a whole.

\subsection{Radiocarbon dates}

Two samples of human bone from two burials were submitted to the Scottish University Environmental Research Centre (SUERC) for analysis. Dating material comprised a femur from F7 and a mandible from F45.

Both dates conform in general terms to that expected from the respective modes of burial. The long-cist is dated to within the 6 th-8th centuries $\mathrm{AD}$, consistent with Hallow Hill, Fife (Proudfoot 1996) and within the overall spread of dates from other recently excavated sites (eg, Greig et al 2000; Rees 2002). The second date, from one of the dug burials, has few immediate parallels in the Lothians; the closest similar site is on the Isle of May (Yeoman 1998). The upper spread of the date range conforms well with the date ascribed to the earliest SWGW pottery, ie mid 12 th century. 


\section{INTERPRETATION}

The evaluation of Kingston Common has provided evidence for activity which, on artefactual grounds alone, spans six millennia, from the Neolithic to the 20th century. This long-term chronology for the site can be refined to indicate two distinct phases of human burial on the knoll, firstly the short-cists and secondly the early medieval cemetery. Within the latter phase, three sub-phases were recognised, sandstone cists without lintels, volcanic stone cists with lintels and dug burials. There was no evidence of a hiatus within the sub-phases.

Notwithstanding the uneven topography of the Kingston Common site and the presence of surface bedrock, a well-ordered long-cist cemetery is apparent, similar to other examples to the south of the Forth (illus 12). The slight changes in alignment within or between the types of long-cists are probably of little consequence; alignments may have been chosen according to the time of year, the availability of space, or the alignment of existing buildings, burials or landscape features. At Thornybank (Rees 2002) and Lasswade (Henshall 1956), sites with few apparent space constraints, the grave alignments were fairly regular and close to north-east-southwest. The burials at Hallow Hill, Fife (Proudfoot 1996) were in general slightly south of east-west and at Lundin Links, Fife (Greig et al 2000) orien- tations on both sides of east-west were recorded. At Kingston, the alignments were more variable, befitting the confined nature of the site and the local geology, where pockets of drift material alternated with both rotten and hard bedrock.

The appearance of what may be a child's long-cist amongst those of adults differs from the situation at Lundin Links, where their absence was assumed to imply burial in a separate location, perhaps associated with the age of baptism (Greig et al 2000, 606).

Alastair Rees (2002) includes a discussion on the locational characteristics of the early medieval cemeteries to the south of the Forth Estuary and summarises the activities that have led to their discovery. Suffice it to say that several themes common to long-cist cemeteries occur at Kingston. The site is visible, and in agricultural land. It is also close to a prehistoric burial site but this does not assume any intended association beyond use of a prominent location. The cemetery as a whole appeared to be unenclosed and was deemed sufficiently defined by its natural topographic location.

No recent excavations of early medieval cemeteries in south-east Scotland have reliably exposed the full extent of the site. Consequently, estimates of the numbers of graves in these cemeteries are fraught

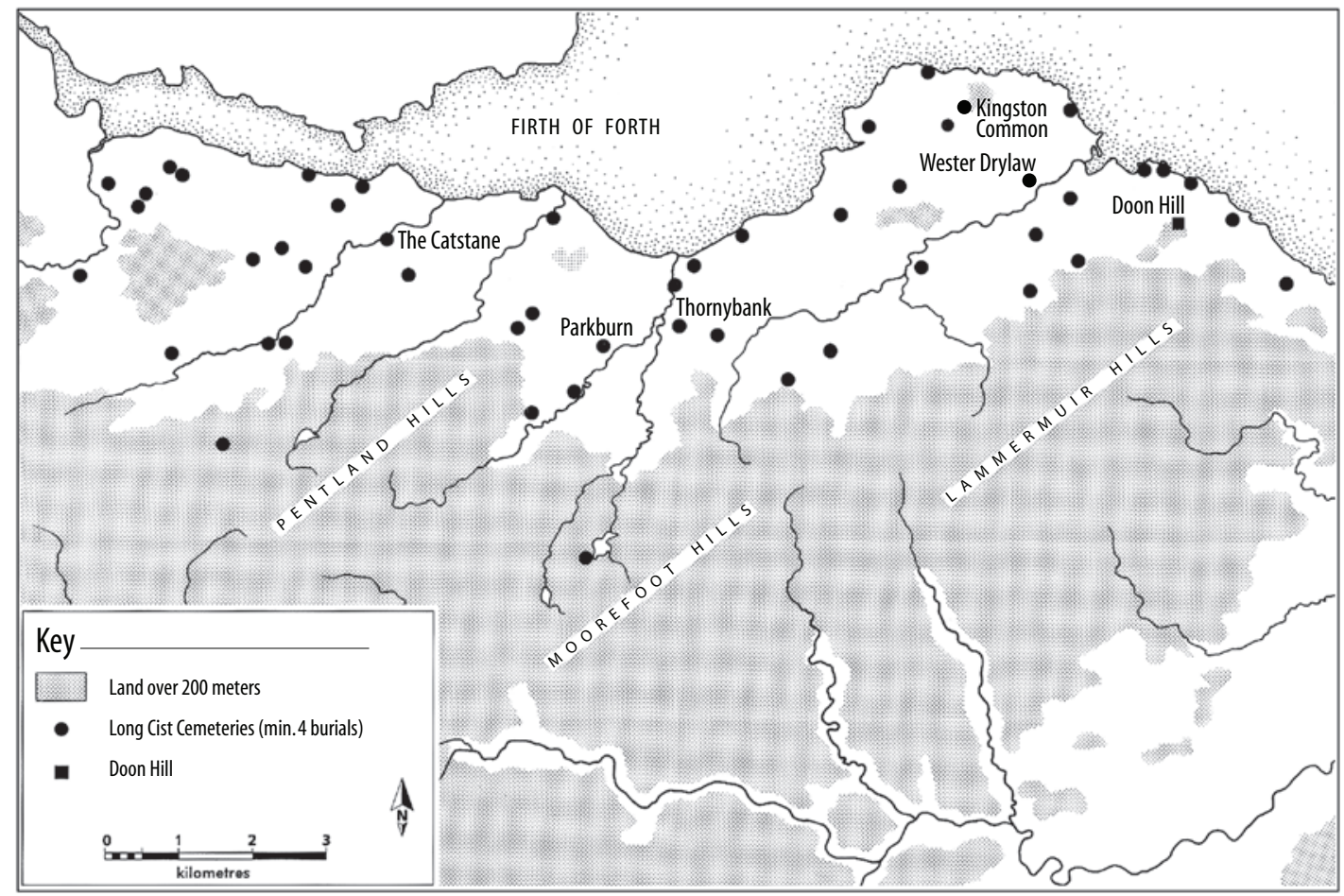

Illus 12 Distribution of long-cist cemeteries south of the River Forth (adapted from Proudfoot 1996 with recent additions) 
with difficulty. Poorly recorded early excavations are an additional handicap on many sites. At Kingston, 42 graves of all types were found in an area representing under 5\% of the approximate Study Area (c $100 \mathrm{~m}^{2}$ of $c 2700 \mathrm{~m}^{2}$ ). This allows no more than an estimation of 200-300 interments on the site given the areas of bedrock and those areas shown to be without graves.

Notwithstanding the limited nature of the fieldwork, there was no evidence of structures contemporary with the long-cists within the excavated areas. Evidence relating to the layout of the cemetery was, however, forthcoming. The prehistoric short-cists lie on the lowest terrace to the east, where an increased soil depth may have allowed easy insertion of burials. Although unexcavated, a Late Neolithic or Early Bronze Age date would be consistent with the Impressed Ware ceramics in the overlying deposits and the structure of the cists, however, earlier dates should not be discounted. Impressed Wares were recovered at both Thornybank (Rees 2002, 317), and on the adjacent A68 Dalkeith bypass (Cameron et al forthcoming), where the long-cist cemetery developed around prehistoric, perhaps ritual, features.

Following the activity surrounding the prehistoric cists and the accumulation of the overlying soil, a long hiatus in the archaeological record is only broken in the mid 1st millennium AD with the appearance of long-cist burials. At Hallow Hill, Fife (Proudfoot 1996; 1998), the level of plough damage meant no distinction could be drawn between long-cists with capstones (lintel graves) and those without. Here, absence of ploughing and the varying geology employed in the construction of the graves allows us scope for the analysis of constructional change through time and a means of relative dating within the cemetery.

The sandstone long-cists are few in number but are located in the centre of the site. The second type of long-cist was much more numerous and used reddish-purple or yellow volcanic stone, with capstones. They were located on the flatter ground to the west and north-west in Trenches 2,5 and the Water Pipe Trench, all outwith the upper and middle terraces. They were also recorded to the north-east of these terraces in Trench 1. Although no cists of the latter type overlay or cut the former, the spatial patterning, with the non-lintelled sandstone cists towards the centre (as defined by the terraces) could suggest that they pre-date those of volcanic stone. It should be remembered that with a spatially or topographically constrained site such as this, models suggesting radiating growth may not be correct. A radiocarbon date from a lintelled cist (F7) indicated that interments within volcanic stone cists were taking place in the 7th century AD.

These interments ceased in the late 1st millennium $\mathrm{AD}$ and a change of burial practice is manifested by the discovery of closely grouped dug graves (F11, F45), within an enclosure, the west wall of which overlay a small, lintelled long-cist (F28), probably a child's grave. Their discovery suggests that burials continued into early medieval times.

A radiocarbon date obtained from a mandible (F45) within a dug grave demonstrated that burials were occurring within a period from the late 10th to the mid 12th centuries. The use of the knoll for burials may have ceased by the 12 th century, or rather later, if ceramic evidence can be taken to signify continuing burials.

A second long-cist underlay the middle terrace, on which may have been sited a small building, perhaps a chapel. Ecclesiastical buildings are not normally associated with long-cist burial sites and Henshall $(1956,274)$ records only one, now destroyed, site of association, namely Mare's Craig Quarry near Newburgh in Fife (also see Close-Brooks 1986, 179). Ecclesiastical buildings at the recently excavated nearby sites of The Hirsel and Auldhame appear not to be more recent than the long-cists (PAshmore, pers comm). Here, the putative structure was spatially associated with the later dug burials in the boulderdefined plot. Were this association to be accepted, it would be comparable in size to Phases 2-3 on the Isle of May, where similar burial structures were uncovered and dated to the early medieval period (Yeoman 1998, 84).

These early medieval chapels were constructed from turf, wood and wattle, sometimes on a stone foundation. Succeeding forms were built primarily of stone. The ratio of length to width (3:2) given by Bateman (1971) cannot be demonstrated at Kingston. As the excavated remains include stone foundations, with mortar present, caution in interpretation is demanded.

Circumstantial supporting evidence for a chapel is provided by the presence of the cross slab in the field wall. Described by Richardson (1906), the cross is of 'Maltese' type, with a recessed design and the date ' 1607 '. He proposes that the date relates to the wall construction, and the current work would not contradict that. Richardson further recalls the names of the adjoining farms, Chapel and Sydserf (illus 1-2) and suggests the existence of an early chapel, not realising its likely proximity.

The Order of St John is recorded as owning 14 acres of tofts and crofts in the nearby town of Gullane in 1458 (Cowan et al 1983). Kingston is not mentioned, but were a chapel on the Common not to be the source of the cross, an origin in Gullane may be an alternative.

The final phase of activity saw the only clear settlement activity within the Study Area. The dwellings were abandoned and removed before 1894. To the north of the knoll proper, artefacts in Trenches 3 and 5 accord well with the cartographic evidence for the existence of cottages in 1854 and their demolition by 1894. The majority of the pottery assemblage dates from the late 18th and early 19 th centuries, with a concentration between 1810 and 1840 . No trenches evaluated the actual site of the cottages. 


\section{$5 \quad$ CONCLUSION}

The limited scale of the Kingston Common project hampers firm conclusions and there is clearly the potential for further targeted fieldwork. Although the site was discovered by accident and lies in a situation unsuited to either farming or commercial development, it shares many traits with those first recorded during these activities and is therefore not an atypical location for an early medieval burial site.

Early medieval cemeteries have been effectively discussed by Greig et al (2000), Henshall (1956), Proudfoot (1996; 1998), Rees (2002), Rees \& Finlayson (1997) and Yeoman (1998). They are considered by many authorities as being a manifestation of the spreading of Christianity (see eg Alcock 1992; Close-Brooks 1984) although Greig et al $(2000,606)$ note that non-Christian RomanoBritish burials share many traits with long-cist burials. These cemeteries have also been viewed as a symbol of territorial arrangements (Proudfoot \& Aliaga-Kelly 1998).

The radiocarbon dates from these cemeteries in south-east Scotland demonstrate that they were in use generally between the 4th and 8th centuries $\mathrm{AD}$, and although more recent excavations may be increasing this date range, the efficacy of several early dates has been questioned (Greig et al 2000; Rees 2002). The single date from the cemetery at Kingston sits comfortably within this framework. The single date from the overlying dug burials has few parallels but also confirms the accepted sequence of stone cists giving way to unlined dug burials.

The fieldwork at Kingston Common has therefore reinforced existing assumptions regarding the location, layout and dating of these cemeteries and that they often occupy burial sites of much greater antiquity. It has also led to the discovery of unusual features, due largely to the beneficial effects accorded to the site by the lack of modern activity on the knoll. Chief amongst these is the possible chapel, a most unusual discovery and one that may repay further work. Due to its vestigial nature, such remains would be rapidly destroyed by agricultural work on many more accessible sites. This further suggests that had overlying cairns existed as at Lundin Links, evidence would have survived.

The aims of the project were intended to be limited and have been fulfilled. The status of the field wall has been established, and does not form a boundary relating to the cemetery. Instead, a date in the 17 th or 18th centuries may be proposed for its construction, either contemporary with the post-medieval settlement or somewhat before it. The boundaries of the cemetery to the east and south have been established, and respect the topography of the knoll. The original cemetery boundaries to the west and north may have been lost, but, within the constraints of the limited trench coverage and the widths of the trenches as against the spacing of the burials, the current limits of the site are now known with a degree of certainty. 


\section{ACKNOWLEDGEMENTS}

CFA wishes to thank the owner of most of Kingston Common, Ian Simpson of Highfield Farm, who was a frequent and interested visitor throughout the course of this project and previous work at Fenton Tower. We would also like to thank Simon Stoddart of Kingston Farm, owner of the remainder of the Common. The work was commissioned and funded by Historic Scotland with the exception of the human bone analysis, which was funded by $\mathrm{Mr}$ Simpson and by the co-developer of Fenton Tower, John Macaskill.

Nick Bridgland of Historic Scotland and Dr Alison
Sheridan of the National Museums of Scotland made site visits and gave valuable advice to the excavator. Derek Hall of Scottish Urban Archaeology Trust provided information about the Order of St John. The contributions of the specialists are gratefully acknowledged. Jonathan Millar drew the pottery sherds. The fieldwork was undertaken primarily by the author and Callum Mitchell. Drafts of the report were commented upon by Sue Anderson and Andrew Dunwell. The final form and opinions expressed in this report remain the responsibility of the author and CFA Archaeology Ltd. 


\section{$7 \quad$ ARCHIVE}

The project archive, comprising all CFA record sheets, plans, reports and full specialist reports will be deposited with the National Monuments Record of Scotland (NMRS). The human remains have been lodged with Historic Scotland's Finds Disposal Panel. 


\section{REFERENCES}

Alcock, E 1992 'Burial and cemeteries in Scotland', in N Edwards \& A Lane (eds) The Early Church in Wales and the West. Recent Work in Early Christian Archaeology, History and Place-names, 125-9. Oxbow Monogr 16, Oxford.

Bateman, W M 1971 'Cemeteries and Chapels', in C Thomas (ed) Early Christian Archaeology, 4888. Oxford University Press, Oxford.

Brothwell, D R, 1965 Digging Up Bones. Cornell University Press, New York.

Buikstra J E and Ubelaker D H (eds) 1994 Standards for Data Collection from Human Skeletal Remains. Arkansas Archaeol Survey Res Ser No 44, Arkansas.

Callander, J G 1929 'Scottish Neolithic Pottery', PSAS, 63 (1928-29), 29-98.

Cameron, K; Cressey, M; Dunwell, A; Mitchell, S; Rees, A; Strachan, R \& Suddaby, I forthcoming Excavations on the Route of the Dalkeith Northern Bypass, 1994-5 and 2006. Scottish Archaeological Internet Reports (SAIR), Edinburgh.

Close-Brooks, J 1984 'Pictish and other burials' in Friell, J G P \& Watson, W G (eds) Pictish Studies. Settlement, Burial and Art in Dark Age Northern Britain, 87-111. Brit Archaeol Rep, Brit Ser, 125, Oxford.

Close-Brooks, J 1986 'Excavations at Clatchard Craig, Fife', PSAS, 116 (1986), 117-84.

Country Life 2003 'Fenton Tower, East Lothian', issue dated 20/11/03, 64-67 (http://www.countrylife.co.uk).

Cowan, I; Mackay, P H R; \& MacQuarrie,A (eds) 1983 The Knights of St John of Jerusalem in Scotland, 66-70. Scottish History Society, Edinburgh.

Galloway, A (ed) 1999 Broken Bones. Charles C Thomas, Illinois.

Greig, C; Greig, M \& Ashmore, P J 2000, 'Excavation of a cairn cemetery at Lundin Links, Fife in 1965-6', PSAS, 130 (2000), 585-636.

Henshall, AS 1956 'A long-cist cemetery at Parkburn sand pit, Lasswade, Midlothian', PSAS, 89 (1955-6), 252-83.

Jones, R; Haggarty, G; Hall, D W \& Will, R 2006 'Sourcing Scottish White Gritty Ware', Medieval Ceramics, 26-27 (2002-3), 45-84.

Kinnes, I A 1985 'Circumstance not context: the Neolithic of Scotland as seen from outside', PSAS, 115 (1985), 15-57.

Lelong, O \& MacGregor, G (eds) forthcoming The Lands of Ancient Lothian: Interpreting the Archaeology of the A1. Soc Antiq Scot, Monogr, Edinburgh.

Longworth, I H 1967 'Further discoveries at Brackmont Mill, Brackmont Farm and Tentsmuir, Fife', PSAS, 49 (1967), 60-92.
McInnes, I J 1964 'The Neolithic and Early Bronze Age pottery from Luce Sands, Wigtownshire', PSAS, 97 (1964), 40-81.

Order of Malta 2008, http://www.orderofmalta.org. uk/index.htm

Ortner D J \& Putschar W G J 1981 Identification of Palaeopathological Conditions in Human Skeletal Remains. Smithsonian Institution Press, Washington DC.

Proudfoot, E 1996 'Excavations at the long-cist cemetery on the Hallow Hill, St Andrews, Fife, 1975-7', PSAS, 126 (1996), 387-454.

Proudfoot, E 1998, 'The Hallow Hill and the origins of Christianity in Eastern Scotland', in B E Crawford (ed) Conversion and Christianity in the North Sea World. Univ of St Andrews Press, St Andrews.

Proudfoot, E \& Aliaga-Kelly, C 1998 'Aspects of settlement and territorial arrangements in South-east Scotland in the late prehistoric and early medieval periods', Medieval Archaeology, 20, 33-50.

Rees, A R \& Finlayson, W L 1997, 'A long-cist burial at Innerwick, near Dunbar, East Lothian', PSAS, 127 (1997), 601-7.

Rees, A R 2002, 'A first millennium AD cemetery, rectangular Bronze Age structure and late prehistoric settlement at Thornybank, Midlothian', PSAS, 132 (2002), 313-356.

Richardson, J S 1906, 'Notice of kitchen midden deposits on North Berwick Law and other antiquities in the vicinity of North Berwick', PSAS, 41 (1906), 424-436.

Sheridan, A 1997, 'Pottery', in D A Johnston 'Biggar Common 1987-93: an early prehistoric funerary and domestic landscape in Clydesdale, South Lanarkshire', PSAS, 127 (1997), $202-23$

Simpson, D D A \& Coles, J M, 1990 'Excavations at Grandtully, Perthshire', PSAS, 120 (1990), $33-44$.

Strachan, R; Ralston, I \& Finlayson, B 1998 'Neolithic and later prehistoric structures, and early medieval metal-working at Blairhall Burn, Amisfield, Dumfriesshire', PSAS, 128 (1998), 55-94.

Suddaby, I 2001 Kingston Common, North Berwick, East Lothian, Archaeological Evaluation. CFA Archaeology Ltd Report No. 638.

Yeoman, P A 1998 'Pilgrims to St Ethernan: the Archaeology of an Early Saint of the Picts and Scots', in B E Crawford (ed) Conversion and Christianity in the North Sea World. Univ of St Andrews Press, St Andrews. 